\title{
COMPARING THE INTERTEMPORAL EFFICIENCY OF ISLAMIC BANKS IN INDONESIA AND MALAYSIA
}

\author{
Lina Nugraha Rani ${ }^{1}$ and Salina Kassim ${ }^{2}$ \\ ${ }^{1}$ Universitas Airlangga, Indonesia, linanugraha@feb.unair.ac.id \\ ${ }^{2}$ International Islamic University Malaysia, Malaysia, ksalina@iium.edu.my
}

\begin{abstract}
This study aims to measure and compare the intertemporal efficiency of Islamic banks in Indonesia and Malaysia using data envelopment analysis (DEA) together with window (intertemporal) analysis for the period 2012-2018 and applying an intermediation approach. Window analysis is used to indicate the stability of efficiency over the study period. The findings show that the intertemporal technical efficiency (TE) of Islamic banks in Indonesia was $77.4 \%$ with stability score of 0.034 , which was significantly more efficient and more stable than Malaysian banks at $75.1 \%$ with stability score of 0.169. Moreover, the the intertemporal pure technical efficiency (PTE) of Islamic banks in Indonesia was $91.7 \%$ with stability score 0.020 , which was also significantly more efficient and more stable than Malaysian banks at $88.0 \%$ PTE and stability score of 0.161. In contrast, the intertemporal scale efficiency (SE) of Islamic banks in Indonesia was $84.5 \%$, slightly lower than that of Malaysian banks at $85.3 \%$ but not significantly different. PTE improvement has contributed to TE improvement, while SE has not reached an optimal level. Comparison to previous results also showed that since the global financial crisis the PTEs of Islamic banks in Indonesia and Malaysia have improved while SEs have worsened. Therefore, efforts to improve SE by expanding the size of Islamic banks to reach optimum economies of scale are urgently needed.
\end{abstract}

Keywords: Efficiency, Islamic banks, Indonesia, Malaysia.

JEL Classification: C14; G18; G21; G28.

Article history:

Received : November 9, 2019

Revised : August 18, 2020

Accepted : August 27, 2020

Available online : November 15, 2020

https://doi.org/10.21098/jimf.v6i4.1147 


\section{INTRODUCTION}

\subsection{Background}

Amid the increasing importance of Islamic banking in many countries globally, current research into the development of Islamic finance in Southeast Asia has provided a model for the development of Islamic finance worldwide. Indonesia and Malaysia have good reputations internationally in the field of Islamic finance development. ASEAN countries such as Indonesia, Malaysia and Brunei are currently particularly vigorous in developing Islamic finance and banking systems. In contrast to Malaysia and Brunei, which use a state-driven approach, the Islamic banking industry in Indonesia is largely market-driven. Countries with Muslim minorities such as Singapore, the Philippines and Thailand are also ASEAN countries with ambitions to develop Islamic finance and banking systems. Up to the year 2018, there were a total of 14 Islamic banks in Indonesia (OJK, 2019) and 16 in Malaysia (Bank Negara Malaysia, 2019).

The development of Islamic banking in Indonesia began with the establishment of Bank Muamalat Indonesia in 1992, supported by the government and implementing a dual banking system in which Islamic banks coexist with conventional banks. As the largest Muslim population in the world, Indonesia needs to provide its Muslim community with Islamic banking services. Malaysia began to implement a dual banking system earlier, and since 1983 had been developing an Islamic financial system with a top-down approach fully supported by the government. The implementation of Islamic banking in many Muslim majority countries would strengthen banking market competition. The quality of management of Islamic banking would become a crucial factor which could affect the efficiency of operation of the Islamic banking sector, highlighting the importance of efficiency level measurement for all existing Islamic banks in ASEAN countries (Solihin, Achsani, \& Saptono, 2016).

Some previous studies have found the Islamic banking industry to be less efficient than conventional banking (Beck, Demirgüç-Kunt, \& Merrouche, 2010; Ariss, 2010), although Ascarya and Yumanita (2008a) found that the efficiency of Islamic banks in Indonesia was relatively better than that of conventional banks. Efficiency is a critical aspect in the performance measurement of Islamic banks, reflecting the ability of Islamic banks to optimize their inputs to produce maximum outputs. For Indonesian Islamic banks this has implications for their ability to compete with other Islamic banks in the region, such as those of its neighbour, Malaysia.

A study by Solikin et al. (2016) using data envelopment analysis (DEA) to compare the efficiency of Islamic banks in ASEAN countries showed that Islamic banks in Indonesia and Malaysia seemed to be competing with each other. This study also found that, implicitly, Malaysian Islamic banks were more efficient than those in Indonesia. In contrast, a study by Ascarya and Yumanita (2008b) using DEA to compare the efficiency of Islamic banks in Indonesia and Malaysia found that Indonesian Islamic banks were more efficient than Malaysian Islamic banks in all three measures of efficiency addressed, namely technical efficiency (TE), pure technical efficiency (PTE) and scale efficiency (SE).

However, no past studies using DEA window analysis to compare the intertemporal efficiency of Islamic banks in Indonesia and Malaysia have been 
found. DEA window analysis was introduced by Charnes, Clark, Cooper, \& Golany (1985) and aimed to provide a better method for measurement of efficiency. Moreover, the previous studies using DEA carried out by Ascarya and Yumanita (2008b) and Solikin et al. (2016) have shown inconclusive results. A new study is therefore needed to compare the intertemporal efficiency of Islamic banks in Indonesia and Malaysia and thus to provide a better illustration of dynamic efficiency.

\subsection{Objective}

The objective of this paper is to compare the efficiency of Islamic banks in Indonesia and Malaysia by applying DEA with window (intertemporal) analysis for the period of 2012 to 2018. In addition, the contribution of this study is to show the movement of Islamic banking efficiency over time during the period of the study to provide a basis for Islamic bank practitioners against which to evaluate their efficiency.

The paper begins with an introductory section describing efficiency in Islamic banks and the development of Islamic banking in Indonesia and Malaysia. The second section reviews the literature, explaining efficiency through examining background, previous studies and conceptual framework. The third section presents the DEA window analysis methodology and explains the data development model. The fourth section presents and analyses the results of the efficiency assessment of Indonesian and Malaysian Islamic banks using DEA window analysis and robustness testing and analysis. The final section presents our conclusions and recommendations.

\section{LITERATURE REVIEW}

\subsection{Theoretical Background}

The measurement of bank efficiency can be achieved using a non-parametric approach such as data envelopment analysis (DEA). This approach was initially introduced and developed by Charnes, Cooper and Rhodes (1978), using linear programming with constant return to scale (CRS) assumptions to calculate relative technical efficiency (TE) and introducing the decision-making unit (DMU) concept. This is also known as the CCR model. DEA is a technique that does not require deterministic assumptions and is not subject to many of the problems of standard statistical estimation of regression parameters, so that there is no need to distinguish between dependent and independent variables or error terms. Subsequently, Banker, Charnes and Cooper (1984) expanded the CRS assumption with the variable return to scale (VRS) assumption, to calculate pure technical efficiency (PTE) and scale efficiency (SE), in which SE is a subtraction of TE with PTE. This model is also known as the BCC model.

Moreover, Charnes et al. (1985) proposed window analysis in DEA, where the performances of institutions (DMUs) are analysed for certain window periods (such as three, four, five, seven, etc.) and moving up to the last period, inspired by moving averages. 
Ascarya and Yumanita (2008) explain that the financial institution efficiency of organizations such as banks can be approached from the perspective of their activities and typically classified into three types: the production or operational approach, the intermediation approach and the asset (or modern) approach. The first two approaches apply classical microeconomic theories of the firm. The production approach describes banking activities as the production of services for depositors and borrowers using all available factors, such as labour and physical capital. The intermediation approach describes banking activities as the intermediary function of the institution in transforming money borrowed from depositors (surplus spending units) into money lent to borrowers (deficit spending units). The third approach improves on these and applies the modified classical theory of the firm by incorporating some specificity to bank activities, including risk management, information processing and some other forms of agency problems.

Wanke, Azad, and Barros, (2016) explain that input and output selection is perhaps the most important task in employing DEA to measure the relative efficiency of DMUs. Under the production approach, banks are treated as firms geared to generating net income/profit in the long run. Such firms 'produce' loans, deposits, and several other kinds of assets using labour, capital and other expenses, while keeping their losses in the production process (provisions) to a minimum. On the other hand, banks are considered as financial intermediaries for transforming assets, deposits, purchased funds and labour into loans and securities under the intermediation approach.

\subsection{Previous Studies}

Islamic banking operates based on the principle of providing an alternative system of banking that is of mutual benefit both to communities and to the banks themselves. The aspect of justice is stressed in transactions, with the emphasis on ethical investments and the values of solidarity and brotherhood in production, as well as on avoidance of speculative activities in financial transactions. Along with the development of Islamic banking, many Islamic banks have been established in the form of Islamic commercial banks, Islamic business units of conventional banks, and Islamic windows or subsidiaries. Several countries with majority Muslim populations, such as Malaysia, Bahrain, the UAE and Indonesia, have shown considerable growth in their Islamic banking systems in recent years (Wanke et al., 2016).

There are plenty of studies measuring the performance/efficiency of Islamic banks with varying results. According to Alqahtani, Mayes, and Brown (2017), banks that have a smaller capacity should be seeking to expand, because the size of bank is found to be associated positively with efficiency. Islamic banks must monitor their capital levels to avoid excess capital, which turns out to have a negative impact on cost efficiency as well as on profit. They must also develop risk management tools that are more innovative, because assets with better quality are associated with higher efficiency.

Shawtari, Ariff, \& Razak (2015) applied DEA window analysis to empirically test the efficiency of Islamic and conventional banks in Yemen, to determine whether the levels of efficiency of conventional and Islamic banks differ significantly from 
each other, as well as to investigate the factors that affect their efficiency. The results show than Yemeni Islamic banks were becoming more efficient over time.

Research to evaluate the efficiency of 114 Islamic banks from 24 countries was carried out by Wanke et al. (2016) using the technique for order preference by similarity to the ideal solution (TOPSIS). TOPSIS is a decision-making technique similar to multicriteria DEA. This technique ranks a set unit based on minimization of the distance from the point of ideal and maximization of existing anti-point distance from the ideal. This research first used the TOPSIS approach in two stages to assess the relative efficiency of Syariah bank, using the indicators most commonly adopted in other literature. Research results indicate that variables associated with the country of origin and fee structure have a noticeable impact on efficiency.

The study conducted by Solihin et al. (2016) using DEA found that in the ASEAN area, competition between Islamic banks only appears in Indonesia and Malaysia and that Brunei, the Philippines, and Singapore have only one Islamic bank each. It was identified that Islamic banks in Indonesia would show lower efficiency than those in Malaysia unless they could reduce their costs of labour and other operational expenses. Moreover, the determining factor of efficiency of Islamic banks in Indonesia was found to be the size of bank, represented by total assets, OPEX/OR and market power.

Alqahtani et al. (2017) conducted a study examining the efficiency of conventional and Islamic banks in Pakistan using DEA. They found that in the long term and in different economic conditions there is no significant difference between Islamic and conventional banks in terms of cost efficiency. Abbas, Azid, and $\mathrm{Hj}$ Besar (2016) examined the efficiency of banks in Pakistan in a comparative study of Islamic and conventional banks and their determinants using standard DEA. Their findings show that the efficiency of Islamic banks is far behind that of conventional banks.

Řepková (2014) conducted a study into Czech banking-sector efficiency using DEA window analysis, also known as 'good efficiency' analysis tools. Repková indicated that the group of large banks was less efficient than other banks and explained this as being because large banks have large deposits and sizeable operational costs.

Research conducted by Webb (2003) also pointed out the importance of using a window analysis approach in research into effectiveness and of using DEA window analysis to investigate the level of efficiency of the relatively sizeable retail banks in the United Kingdom during the period of transition of 1982-1995. It appears from the entire sample that the average level of inefficiency was low compared to previous studies, that the average efficiency trends for the long term dropped overall, and that all banks in this study showed a reduction in level of efficiency during the entire period.

Research conducted by Ascarya and Yumanita (2008) examined the comparative efficiency of Islamic banks in Malaysia and Indonesia using DEA and an intermediation approach, and showed that Islamic banks in Indonesia were more efficient than Malaysian banks in all three measurements, namely overall technical efficiency, pure technical efficiency and scale efficiency. Meanwhile, human resources was shown to be one of the sources of inefficiency in Indonesia. 


\section{METHODOLOGY}

\subsection{Data}

This study uses data for Islamic banks in Indonesia and Malaysia for the period 2012 to 2018 to investigate the performance of Islamic banks since the global financial crisis. The data were collected from the annual financial reports released on each Islamic bank's website (attached). Financial report is very important to illustrate level of company decision that represent by level of relevance and reliability. Since several Islamic banks were not been established in 2012 and thus their financial statements were incomplete for the study period, the data for the present study were gathered from 11 Islamic banks in Indonesia and 15 Islamic banks in Malaysia.

\subsection{Model development}

This study applies DEA window analysis to compare the efficiency of Islamic banks in Indonesia and Malaysia. Following Ascarya and Yumanita (2008) and Kamarudin, Hue, Sufian, and Mohamad Anwar (2017), we consider Islamic banks in their roles as intermediary institutions and so an intermediation approach was selected with input-output variables selected accordingly. The input variables used are labour costs (X1), fixed assets (X2), and total deposits or third-party funds (X3), while the output variables are total financing (Y1), operating income (Y2), and investment portfolio (Y3).

INPUT

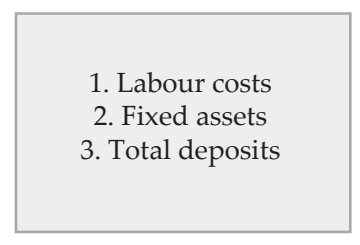



TE $=$ PTE $\times$ SE

\section{OUTPUT}

1. Total financing

2. Operating income

3. Investment portfolio

Note: TE = technical efficiency; PTE = pure technical efficiency; and SE = scale efficiency.

Figure 1.

Model Development of DEA Efficiency Measurement

Efficiency measures will be technical efficiency (TE) based on constant return to scale assumptions by Charnes et al. (1978) (or CCR), pure technical efficiency (PTE) based on variable return to scale (VRS) assumptions by Barnes et al. (1984) (or BCR), as well as scale efficiency (SE) as represented by TE/PTE. Meanwhile, the DEA window analysis will follow the methods of Charnes et al. (1985) and Cooper et al. (2011).

Using DEA, comparison of the relative efficiency of similar decision-making units (DMUs) in two or more periods of a different kind is unanalysable. Thus, an intertemporal perspective is applied to compare the efficiency over time (change of efficiency) of the sample itself. This requires the use of a method of analysis appropriate to revealing the intertemporal (window) efficiency of the industry. 


\subsection{Method}

According to Jahanshahloo, Soleimani-Damaneh, and Ghobadi (2015), the traditional DEA model evaluates static data without any regard to the determination of the time factor. Later on came the development of DEA dynamics, involving the measurement of DMUs by considering time and intertemporal factors depending on the level of input-output through an analysis of the DEA framework. Intertemporal DEA analyses performance through assessment by the window method.

DEA window analysis is used to find out the level of efficiency of each Islamic bank from time to time (i.e. intertemporally). This method calculates the efficiency of an Islamic bank in a certain moving window period in terms of a) largest difference between scores per window (LDW), which measures the difference between the most substantial score of efficiency in one window; $b$ ) largest difference between scores in the same year (LDY), which measures the largest difference of a bank efficiency in the same year but different window; and c) largest difference between scores across the entire period (LDP), measuring the largest difference of a bank efficiency in the entire observation period (Sufian \& Majid, 2006).

DEA window analysis adopts the concept of the moving average, where the next window data adds one new data period and removes the oldest data period, as can be seen in Table 1. There is no particular scientific justification for window size (Sufian \& Majid, 2006) and so although most studies have used a 3-year window, following Charnes et al. (1985), to cover a longer period, a 4-year window following Cooper, Seiford, and Tone (2007, p. 324) will be used here.

Table 1.

Window Breakdown

\begin{tabular}{ccccccccc}
\hline WINDOW & 2012 & 2013 & 2014 & 2015 & 2016 & 2017 & 2018 & $\begin{array}{c}\text { Intertemporal } \\
\text { efficiency }\end{array}$ \\
\hline Window 1 & Eff & Eff & Eff & Eff & & & & $2012-2015$ \\
Window 2 & & Eff & Eff & Eff & Eff & & & $2013-2016$ \\
Window 3 & & & Eff & Eff & Eff & Eff & & $2014-2017$ \\
Window 4 & & & & Eff & Eff & Eff & Eff & $2015-2018$ \\
& & & & & & & & Mean \\
\hline
\end{tabular}

Note: Eff is efficiency, which could be TE or PTE

The efficiency stability scores of LDW, LDY and LDP will describe conditions in which a smaller score shows more stable efficiency. Intertemporal DEA efficiency comprises technical efficiency (TE) assuming constant return to scale (CRS) and pure technical efficiency (PTE) assuming variable return to scale (VRS), as well as scale efficiency (SE), which can be calculated by dividing TE by PTE.

\section{RESULTS AND ANALYSIS}

\subsection{Results}

Various calculations of Islamic banks' efficiencies will be presented here, including the efficiency of all years of the study from 2012 to 2018, the efficiency of each year 
of the study, and, finally, intertemporal efficiency for technical efficiency (TE), pure technical efficiency (PTE) and scale efficiency (SE).

\subsubsection{Efficiency of Islamic Banks in Indonesia and Malaysia for the Years 2012} to 2018.

Table 2 shows the results for the efficiency of Indonesian and Malaysian Islamic banks for the period 2012 to 2018. On average, Indonesian Islamic banks were more efficient than Malaysian Islamic banks in all three efficiency measures, namely TE, PTE and SE. TE of Indonesian Islamic banks was 0.754, comprising 0.891 PTE and 0.904 SE, while TE of Malaysian Islamic banks was 0.541, comprising 0.695 PTE and $0.788 \mathrm{SE}$.

Table 2.

Efficiency of Islamic Banks in Indonesia and Malaysia 2012-2018

\begin{tabular}{clccc}
\hline No. & \multicolumn{1}{c}{ DMU } & $\begin{array}{c}\text { Technical } \\
\text { Efficiency } \\
\text { (CRS) }\end{array}$ & $\begin{array}{c}\text { Pure technical } \\
\text { Efficiency } \\
\text { (VRS) }\end{array}$ & $\begin{array}{c}\text { Scale } \\
\text { Efficiency } \\
\text { (CRS/VRS) }\end{array}$ \\
\hline Indonesian Islamic banks & & & \\
\hline 1 & BCA Syariah & 0.673 & 0.735 & 0.929 \\
2 & Bank Muamalat Indonesia & 0.732 & 0.931 & 0.925 \\
3 & Bank Mega Syariah & 0.603 & 0.967 & 0.921 \\
4 & BRI Syariah & 0.691 & 0.922 & 0.917 \\
5 & BNI Syariah & 0.534 & 0.845 & 0.630 \\
6 & Bank Syariah Mandiri & 0.959 & 1.000 & 0.959 \\
7 & Bank Bukopin Syariah & 0.614 & 0.644 & 0.953 \\
8 & BJB Syariah & 0.708 & 0.907 & 0.778 \\
9 & Maybank Syariah & 0.946 & 0.959 & 0.986 \\
10 & Panin Dubai Syariah Bank & 0.930 & 0.950 & 0.978 \\
11 & Bank Victoria Syariah & 0.903 & 0.935 & 0.968 \\
& MEAN & $\mathbf{0 . 7 5 4}$ & $\mathbf{0 . 8 9 1}$ & $\mathbf{0 . 9 0 4}$ \\
\hline Malaysian Islamic Banks & & & \\
\hline 1 & Affin Islamic Bank Berhad & 0.448 & 0.637 & 0.747 \\
2 & Al Rajhi Islamic Bank & 0.229 & 0.279 & 0.830 \\
3 & Alliance Islamic Bank Berhad & 0.854 & 0.891 & 0.958 \\
4 & Bank Islam Malaysia Berhad & 0.370 & 0.972 & 0.378 \\
5 & Bank Muamalat Malaysia Berhad & 0.373 & 0.873 & 0.428 \\
6 & CIMB Islamic Bank Berhad & 0.567 & 0.770 & 0.728 \\
7 & Hong Leong Islamic Bank Berhad & 0.462 & 0.472 & 0.979 \\
8 & HSBC Amanah Malaysia Berhad & 0.433 & 0.458 & 0.956 \\
9 & KFH Malaysia Berhad & 0.396 & 0.420 & \\
\hline & & & & \\
\hline
\end{tabular}


Table 2.

Efficiency of Islamic Banks in Indonesia and Malaysia 2012-2018 (Continued)

\begin{tabular}{llccc}
\hline No. & \multicolumn{1}{c}{ DMU } & $\begin{array}{c}\text { Technical } \\
\text { Efficiency } \\
\text { (CRS) }\end{array}$ & $\begin{array}{c}\text { Pure technical } \\
\text { Efficiency } \\
\text { (VRS) }\end{array}$ & $\begin{array}{c}\text { Scale } \\
\text { Efficiency } \\
\text { (CRS/VRS) }\end{array}$ \\
\hline 10 & Maybank Islamic Berhad & 0.896 & 0.928 & 0.963 \\
11 & MBSB Bank Berhad & 0.214 & 0.539 & 0.404 \\
12 & OCBC Al Amin Bank Berhad & 0.707 & 0.750 & 0.944 \\
13 & Public Islamic Bank Berhad & 0.938 & 0.945 & 0.991 \\
14 & RHB Islamic Bank Berhad & 0.457 & 0.551 & 0.784 \\
15 & Standard Chartered Saadiq Berhad & 0.773 & 0.941 & 0.819 \\
& MEAN & $\mathbf{0 . 5 4 1}$ & $\mathbf{0 . 6 9 5}$ & $\mathbf{0 . 7 8 8}$ \\
\hline
\end{tabular}

4.1.2. Intertemporal Technical Efficiency (TE) of Islamic Banks in Indonesia and Malaysia Using Window Analysis

Table 3 shows the results for intertemporal technical efficiency (TE) of Islamic banks in Indonesia and Malaysia using DEA window analysis, including the average (mean), long distance period (LDP) and long distance per year (LDY), to reveal the stability of bank efficiency. Based on the results, it can be concluded that the average intertemporal TE of Indonesian Islamic banks was 0.774, which was more efficient than that of Malaysian Islamic banks at 0.751 . The TE stability (LDY) of Indonesian Islamic banks was 0.034, and was thus also more stable than that of Malaysian Islamic banks at 0.169 .

The most efficient Islamic banks were Bank Syariah Mandiri (0.984) in Indonesia and Public Islamic Bank Berhad (1.000) in Malaysia, the latter being the most efficient overall. However, the most TE stable Islamic banks were Bank Victoria Syariah and Maybank Syariah in Indonesia, with LDY of 0.000, and Public Islamic Bank Berhad, Maybank Islamic Berhad, OCBC Al Amin Bank Berhad and Alliance Islamic Bank Berhad in Malaysia, also all with LDY of 0.000.

Meanwhile, the least efficient Islamic bank was BNI Syariah (0.609) in Indonesia and Al Rajhi Islamic Bank (0.538) in Malaysia, while the least stable TE was in BRI Syariah in Indonesia with LDY of 0.114, and KFH Malaysia Berhad in Malaysia with LDY of 0.472 .

Table 3.

Intertemporal Technical Efficiency (TE) of Islamic Banks in Indonesia and Malaysia Using Window Analysis

\begin{tabular}{llcccccccc}
\hline No. & \multicolumn{1}{c}{ DMU } & $\begin{array}{r}\mathbf{2 0 1 2 -} \\
\mathbf{2 0 1 5}\end{array}$ & $\begin{array}{c}\mathbf{2 0 1 3}- \\
\mathbf{2 0 1 6}\end{array}$ & $\begin{array}{c}\mathbf{2 0 1 4 -} \\
\mathbf{2 0 1 7}\end{array}$ & $\begin{array}{c}\mathbf{2 0 1 5 -} \\
\mathbf{2 0 1 8}\end{array}$ & Mean & LDP & LDY & Rank \\
\hline Indonesian Islamic banks & & & & & & & & \\
\hline 1 & BCA Syariah & 0.65 & 0.704 & 0.735 & 0.764 & 0.713 & 0.111 & 0.034 & 7 \\
2 & Bank Muamalat Indonesia & 0.754 & 0.706 & 0.691 & 0.735 & 0.722 & 0.106 & 0.003 & 6 \\
3 & Bank Mega Syariah & 0.662 & 0.663 & 0.623 & 0.625 & 0.643 & 0.305 & 0.073 & 9 \\
4 & BRI Syariah & 0.595 & 0.675 & 0.754 & 0.828 & 0.713 & 0.194 & 0.114 & 8 \\
5 & BNI Syariah & 0.533 & 0.669 & 0.616 & 0.619 & 0.609 & 0.370 & 0.049 & 11 \\
\hline
\end{tabular}


Table 3.

Intertemporal Technical Efficiency (TE) of Islamic Banks in Indonesia and Malaysia Using Window Analysis (Continued)

\begin{tabular}{|c|c|c|c|c|c|c|c|c|c|}
\hline No. & DMU & $\begin{array}{c}2012- \\
2015\end{array}$ & $\begin{array}{c}2013- \\
2016\end{array}$ & $\begin{array}{c}2014- \\
2017\end{array}$ & $\begin{array}{c}2015- \\
2018\end{array}$ & Mean & LDP & LDY & Rank \\
\hline 6 & Bank Syariah Mandiri & 0.989 & 0.991 & 0.977 & 0.977 & 0.984 & 0.046 & 0.012 & 1 \\
\hline 7 & Bank Bukopin Syariah & 0.647 & 0.64 & 0.608 & 0.642 & 0.634 & 0.131 & 0.023 & 10 \\
\hline 8 & BJB Syariah & 0.83 & 0.775 & 0.729 & 0.68 & 0.754 & 0.459 & 0.015 & 5 \\
\hline 9 & Maybank Syariah & 1 & 0.999 & 0.964 & 0.921 & 0.971 & 0.290 & 0.000 & 3 \\
\hline 10 & Panin Dubai Syariah Bank & 0.972 & 0.97 & 0.957 & 0.92 & 0.955 & 0.220 & 0.049 & 4 \\
\hline \multirow[t]{2}{*}{11} & Bank Victoria Syariah & 0.970 & 0.970 & 0.963 & 0.990 & 0.973 & 0.119 & 0.000 & 2 \\
\hline & Mean & 0.764 & 0.784 & 0.770 & 0.779 & 0.774 & 0.214 & 0.034 & \\
\hline \multicolumn{10}{|c|}{ Malaysian Islamic banks } \\
\hline 1 & Affin Islamic Bank Bhd & 0.631 & 0.648 & 0.633 & 0.454 & 0.592 & 0.211 & 0.086 & 14 \\
\hline 2 & Al Rajhi Islamic Bank & 0.612 & 0.69 & 0.614 & 0.235 & 0.538 & 0.134 & 0.313 & 15 \\
\hline 3 & Alliance Islamic Bank Bhd & 0.96 & 0.9 & 0.867 & 0.807 & 0.884 & 0.243 & 0.000 & 5 \\
\hline 4 & Bank Islam Malaysia Bhd & 0.698 & 0.716 & 0.614 & 0.378 & 0.602 & 0.205 & 0.387 & 12 \\
\hline 5 & Bank Muamalat Malaysia Bhd & 0.68 & 0.857 & 0.701 & 0.358 & 0.649 & 0.104 & 0.321 & 11 \\
\hline 6 & CIMB Islamic Bank Bhd & 0.675 & 0.736 & 0.82 & 0.655 & 0.722 & 0.193 & 0.114 & 7 \\
\hline 7 & Hong Leong Islamic Bank Bhd & 0.731 & 0.791 & 0.749 & 0.476 & 0.687 & 0.230 & 0.185 & 9 \\
\hline 8 & HSBC Amanah Malaysia Bhd & 0.813 & 0.802 & 0.772 & 0.433 & 0.705 & 0.248 & 0.185 & 8 \\
\hline 9 & KFH Malaysia Bhd & 0.889 & 0.916 & 0.926 & 0.528 & 0.815 & 0.197 & 0.472 & 6 \\
\hline 10 & Maybank Islamic Bhd & 0.987 & 0.978 & 0.992 & 0.99 & 0.987 & 0.040 & 0.000 & 2 \\
\hline 11 & MBSB Bank Bhd & 0.859 & 0.706 & 0.622 & 0.217 & 0.601 & 0.150 & 0.347 & 13 \\
\hline 12 & OCBC Al Amin Bank Bhd & 0.963 & 0.972 & 0.857 & 0.747 & 0.885 & 0.306 & 0.000 & 4 \\
\hline 13 & Public Islamic Bank Bhd & 1 & 1 & 1 & 1 & 1 & 0.000 & 0.000 & 1 \\
\hline 14 & RHB Islamic Bank Bhd & 0.535 & 0.617 & 0.733 & 0.737 & 0.656 & 0.274 & 0.123 & 10 \\
\hline \multirow[t]{2}{*}{15} & Standard Chartered Saadiq Bhd & 0.954 & 0.945 & 0.924 & 0.957 & 0.945 & 0.174 & 0.001 & 3 \\
\hline & Mean & 0.799 & 0.818 & 0.788 & 0.598 & 0.751 & 0.176 & 0.169 & \\
\hline
\end{tabular}

Further results shows that the five most technically efficient Islamic banks in Indonesia were Bank Syariah Mandiri (0.984), Victoria Syariah (0.973), Maybank Syariah (0.971), Panin Dubai Syariah (0.955), and Bank Jawa Barat Syariah (0.754). Meanwhile, the five most technically efficient Islamic banks in Malaysia were Public Islamic Bank Berhad (1.000), Maybank Islamic Berhad (0.987), Standard Chartered Saadiq Berhad (0.945), OCBC Al Amin Bank Berhad (0.885), and Alliance Islamic Bank Berhad (0.884).

\subsubsection{Window Analysis of Pure Technical Efficiency (PTE) of Islamic Banks in Indonesia and Malaysia}

Table 4 shows the intertemporal pure technical efficiency (PTE) results for Islamic banks in Indonesia and Malaysia using DEA window analysis. The results show 
that the average intertemporal PTE of Islamic banks in Indonesia was 0.917, which was better that that of Islamic banks in Malaysia at 0.880. The PTE stability (LDY) of Indonesian Islamic banks was 0.020, which was also more stable than Malaysian Islamic banks at 0.161 .

The most efficient Islamic banks were Bank Syariah Mandiri (1.000) in Indonesia and Public Islamic Bank Berhad (1.000) in Malaysia, while the most PTE-stable Islamic banks were Bank Syariah Mandiri, Bank Mega Syariah, Bank Victoria Syariah, Maybank Syariah and BRI Syariah in Indonesia with LDY of 0.000, and Public Islamic Bank Berhad, Maybank Islamic Berhad, CIMB Islamic Berhad, OCBC Al Amin Bank Berhad and Alliance Islamic Bank Berhad in Malaysia, also with LDY of 0.000 .

Meanwhile, the least efficient Islamic banks were Bukopin Syariah (0.680) in Indonesia and Al Rajhi Islamic Bank (0.596) in Malaysia, while the least PTE-stable Islamic banks were Bank Bukopin Syariah in Indonesia with LDY of 0.100, and KFH Malaysia Berhad in Malaysia with LDY of 0.457.

Table 4.

Intertemporal Pure Technical Efficiency (PTE) of Islamic Banks in Indonesia and Malaysia Using Window Analysis

\begin{tabular}{|c|c|c|c|c|c|c|c|c|c|}
\hline No. & DMU & $\begin{array}{c}2012- \\
2015\end{array}$ & $\begin{array}{c}2013- \\
2016\end{array}$ & $\begin{array}{c}2014- \\
2017\end{array}$ & $\begin{array}{c}2015- \\
2018\end{array}$ & Mean & LDP & LDY & Rank \\
\hline \multicolumn{10}{|c|}{ Indonesian Islamic banks } \\
\hline 1 & BCA Syariah & 0.708 & 0.796 & 0.835 & 0.889 & 0.937 & 0.180 & 0.028 & 10 \\
\hline 2 & Bank Muamalat Indonesia & 0.983 & 0.93 & 0.898 & 0.938 & 0.989 & 0.160 & 0.030 & 8 \\
\hline 3 & Bank Mega Syariah & 0.981 & 1 & 0.984 & 0.992 & 0.947 & 0.051 & 0.000 & 2 \\
\hline 4 & BRI Syariah & 0.9 & 0.928 & 0.966 & 0.994 & 0.947 & 0.047 & 0.000 & 6 \\
\hline 5 & BNI Syariah & 0.948 & 0.916 & 0.957 & 0.954 & 0.944 & 0.094 & 0.004 & 7 \\
\hline 6 & Bank Syariah Mandiri & 1 & 1 & 1 & 1 & 1 & 0.000 & 0.000 & 1 \\
\hline 7 & Bank Bukopin Syariah & 0.668 & 0.682 & 0.698 & 0.670 & 0.680 & 0.112 & 0.100 & 11 \\
\hline 8 & BJB Syariah & 0.959 & 0.919 & 0.885 & 0.897 & 0.915 & 0.276 & 0.036 & 9 \\
\hline 9 & Maybank Syariah & 1 & 1 & 0.97 & 0.928 & 0.975 & 0.287 & 0.000 & 4 \\
\hline 10 & Panin Dubai Syariah Bank & 0.973 & 1 & 0.973 & 0.943 & 0.972 & 0.129 & 0.019 & 5 \\
\hline \multirow[t]{2}{*}{11} & Bank Victoria Syariah & 0.982 & 0.982 & 0.967 & 1 & 0.983 & 0.073 & 0.000 & 3 \\
\hline & Mean & 0.911 & 0.917 & 0.917 & 0.923 & 0.917 & 0.128 & 0.020 & \\
\hline \multicolumn{10}{|c|}{ Malaysian Islamic banks } \\
\hline 1 & Affin Islamic Bank Bhd & 0.872 & 0.881 & 0.955 & 0.669 & 0.844 & 0.315 & 0.282 & 10 \\
\hline 2 & Al Rajhi Islamic Bank & 0.668 & 0.748 & 0.651 & 0.318 & 0.596 & 0.178 & 0.268 & 15 \\
\hline 3 & Alliance Islamic Bank Bhd & 0.975 & 0.929 & 0.898 & 0.833 & 0.909 & 0.339 & 0.000 & 8 \\
\hline 4 & Bank Islam Malaysia Bhd & 1 & 0.982 & 0.997 & 0.997 & 0.994 & 0.029 & 0.012 & 3 \\
\hline 5 & Bank Muamalat Malaysia Bhd & 0.985 & 0.974 & 0.98 & 0.949 & 0.972 & 0.109 & 0.003 & 4 \\
\hline 6 & CIMB Islamic Bank Bhd & 1 & 0.981 & 0.989 & 0.861 & 0.958 & 0.076 & 0.000 & 6 \\
\hline 7 & Hong Leong Islamic Bank Bhd & 0.833 & 0.922 & 0.918 & 0.483 & 0.789 & 0.234 & 0.456 & 14 \\
\hline 8 & HSBC Amanah Malaysia Bhd & 0.92 & 0.96 & 0.983 & 0.454 & 0.829 & 0.061 & 0.456 & 12 \\
\hline
\end{tabular}


Table 4.

Intertemporal Pure Technical Efficiency (PTE) of Islamic Banks in Indonesia and Malaysia Using Window Analysis (Continued)

\begin{tabular}{clcccccccc}
\hline \multirow{2}{*}{ No. } & \multicolumn{1}{c}{ DMU } & $\mathbf{2 0 1 2 -}$ & $\mathbf{2 0 1 3 -}$ & $\mathbf{2 0 1 4 -}$ & $\mathbf{2 0 1 5 -}$ & \multirow{2}{*}{ Mean } & LDP & LDY & Rank \\
\hline 9 & KFH Malaysia Bhd & 0.919 & 0.944 & 0.959 & 0.552 & 0.844 & 0.249 & 0.457 & 11 \\
10 & Maybank Islamic Bhd & 1 & 0.99 & 1 & 0.998 & 0.997 & 0.000 & 0.000 & 2 \\
11 & MBSB Bank Bhd & 0.999 & 1 & 0.982 & 0.553 & 0.884 & 0.136 & 0.372 & 9 \\
12 & OCBC Al Amin Bank Bhd & 0.982 & 0.979 & 0.912 & 0.803 & 0.919 & 0.123 & 0.000 & 7 \\
13 & Public Islamic Bank Bhd & 1 & 1 & 1 & 1 & 1 & 0.000 & 0.000 & 1 \\
14 & RHB Islamic Bank Bhd & 0.798 & 0.821 & 0.815 & 0.772 & 0.802 & 0.267 & 0.106 & 13 \\
15 & Standard Chartered Saadiq Bhd & 0.991 & 0.985 & 0.937 & 0.957 & 0.968 & 0.173 & 0.004 & 5 \\
& Mean & 0.924 & 0.937 & 0.927 & $\mathbf{0 . 7 0 9}$ & 0.880 & $\mathbf{0 . 1 5 3}$ & $\mathbf{0 . 1 6 1}$ & \\
\hline
\end{tabular}

The five most pure-technically efficient Islamic banks in Indonesia were Bank Syariah Mandiri (1.000), Bank Mega Syariah (0.947), Victoria Syariah (0983), Maybank Syariah (0.975), and Bank Panin Dubai Syariah (0.972). Meanwhile, the five most pure-technically efficient Islamic banks in Malysia were Public Islamic Bank Berhad (1.000), Maybank Islamic Berhad (0.997), Bank Islam Malaysia Berhad (0.994), Bank Muamalat Malaysia Berhad (0.972), and Standard Chartered Saadiq Berhad (0.968).

\subsubsection{Window Analysis of Scale Efficiency (SE) of Islamic Banks in Indonesia and Malaysia}

Table 5 shows the intertemporal scale efficiency (SE) results for Islamic banks in Indonesia and Malaysia using DEA window analysis. Scale efficiency (SE) is calculated by dividing technical efficiency (TE) by pure technical efficiency (PTE) as previously calculated. The maximum TE/PTE is 1.000 or fully scale efficient, so TE would always be less than or equal to PTE.

The results show that the average intertemporal SE of Islamic banks in Indonesia was 0.845 , which was slightly less efficient than that of banks in Malaysia at 0.853 . The most scale-efficient Islamic banks were Maybank Syariah (0.996) in Indonesia and Public Islamic Bank Berhard (1.000) in Malaysia.

Moreover, the five most scale-efficient Islamic banks in Indonesia were Maybank Syariah (0.996), Victoria Syariah (0.991), Bank Syariah Mandiri (0.984), Panin Dubai Syariah (0.982) and Bank Bukopin Syariah (0.933). Meanwhile, the five most scale-efficient Islamic banks in Malaysia were Public Islamic Bank Berhad (1.000), Maybank Islamic Berhad (0.990), Standard Chartered Saadiq Berhad (0.977), Alliance Islamic Bank Berhad (0.972) and KFH Malaysia Berhad (0.966). 
Table 5.

Intertemporal Scale Efficiency (SE) of Islamic Banks in Indonesia and Malaysia Using Window Analysis

\begin{tabular}{|c|c|c|c|c|}
\hline No. & DMU & $\begin{array}{l}\text { Technical } \\
\text { Efficiency } \\
\text { (CRS) }\end{array}$ & $\begin{array}{l}\text { Pure technical } \\
\text { Efficiency } \\
\text { (VRS) }\end{array}$ & $\begin{array}{c}\text { Scale } \\
\text { Efficiency } \\
\text { (CRS/VRS) }\end{array}$ \\
\hline \multicolumn{5}{|c|}{ Indonesian Islamic banks } \\
\hline 1 & BCA Syariah & 0.713 & 0.937 & 0.761 \\
\hline 2 & Bank Muamalat Indonesia & 0.722 & 0.989 & 0.729 \\
\hline 3 & Bank Mega Syariah & 0.643 & 0.947 & 0.679 \\
\hline 4 & BRI Syariah & 0.713 & 0.947 & 0.753 \\
\hline 5 & BNI Syariah & 0.609 & 0.944 & 0.646 \\
\hline 6 & Bank Syariah Mandiri & 0.984 & 1.000 & 0.984 \\
\hline 7 & Bank Bukopin Syariah & 0.634 & 0.680 & 0.933 \\
\hline 8 & BJB Syariah & 0.754 & 0.915 & 0.823 \\
\hline 9 & Maybank Syariah & 0.971 & 0.975 & 0.996 \\
\hline 10 & Panin Dubai Syariah Bank & 0.955 & 0.972 & 0.982 \\
\hline \multirow[t]{2}{*}{11} & Bank Victoria Syariah & 0.973 & 0.983 & 0.991 \\
\hline & MEAN & 0.774 & 0.917 & 0.845 \\
\hline \multicolumn{5}{|c|}{ Malaysian Islamic banks } \\
\hline 1 & Affin Islamic Bank Berhad & 0.592 & 0.844 & 0.701 \\
\hline 2 & Al Rajhi Islamic Bank & 0.538 & 0.596 & 0.902 \\
\hline 3 & Alliance Islamic Bank Berhad & 0.884 & 0.909 & 0.972 \\
\hline 4 & Bank Islam Malaysia Berhad & 0.602 & 0.994 & 0.605 \\
\hline 5 & Bank Muamalat Malaysia Berhad & 0.649 & 0.972 & 0.668 \\
\hline 6 & CIMB Islamic Bank Berhad & 0.722 & 0.958 & 0.753 \\
\hline 7 & Hong Leong Islamic Bank Berhad & 0.687 & 0.789 & 0.870 \\
\hline 8 & HSBC Amanah Malaysia Berhad & 0.705 & 0.829 & 0.850 \\
\hline 9 & KFH Malaysia Berhad & 0.815 & 0.844 & 0.966 \\
\hline 10 & Maybank Islamic Berhad & 0.987 & 0.997 & 0.990 \\
\hline 11 & MBSB Bank Berhad & 0.601 & 0.884 & 0.680 \\
\hline 12 & OCBC Al Amin Bank Berhad & 0.885 & 0.919 & 0.963 \\
\hline 13 & Public Islamic Bank Berhad & 1.000 & 1.000 & 1.000 \\
\hline 14 & RHB Islamic Bank Berhad & 0.656 & 0.802 & 0.818 \\
\hline \multirow[t]{2}{*}{15} & Standard Chartered Saadiq Berhad & 0.945 & 0.968 & 0.977 \\
\hline & MEAN & 0.751 & 0.880 & 0.853 \\
\hline
\end{tabular}




\subsection{Robustness Test}

Here, the differences between average efficiency of Islamic banks in Indonesia and Malaysia is tested by first checking data normality. If the data are normally distributed, paired sample T-testing will be conducted, while if the data are not normally distributed, the Mann-Whitney U-test will be used. Table 6 shows the results of normality tests, revealing that TE and PTE figures for Islamic banks in Indonesia and Malaysia are not normally distributed, since all data show significant results at $5 \%$ significance level or $p<5 \%$ and therefore Ho is rejected. Therefore, as the next step, Mann-Whitney U-testing is performed to test for differences between the efficiency of Islamic banks in Indonesia and Malaysia.

Table 6.

Results of Normality Tests

\begin{tabular}{lccccc}
\hline \multicolumn{7}{c}{ Shapiro-Francia $\mathbf{W}$ test for normal data } \\
\hline \multicolumn{1}{c}{ Variable } & Obs & $\mathbf{W}^{\prime}$ & $\mathbf{V}^{\prime}$ & $\mathbf{z}$ & Prob $>\mathbf{z}$ \\
\hline TE Indonesia & 77 & 0.95779 & 3.103 & 2.200 & 0.01389 \\
TE Malaysia & 105 & 0.93277 & 6.369 & 3.671 & 0.00012 \\
PTE Indonesia & 77 & 0.95267 & 3.479 & 2.423 & 0.00770 \\
PTE Malaysia & 105 & 0.96581 & 3.239 & 2.330 & 0.00989 \\
SE Indonesia & 77 & 0.89108 & 7.246 & 4.330 & 0.00001 \\
SE Malaysia & 105 & 0.83229 & 14.424 & 5.936 & 0.00000 \\
\hline
\end{tabular}

Table 7 shows the results of Mann-Whitney U-testing for differences between the efficiency of Islamic banks in Indonesia and Malaysia, revealing that the average TE of Indonesian Islamic banks (TE Indonesia) is different (higher than) the average TE of Malaysian Islamic banks (TE Malaysia), where probability $\mathrm{z}$ is 0.0000 and Ho accepted is that TE Indonesia is different from (higher than) TE Malaysia. PTE Indonesia is different from (higher than) PTE Malaysia, with probability z of 0.0000 . Moreover, SE Indonesia is not different from SE Malaysia, with probability $\mathrm{z}$ of 0.3769 .

Table 7.

Results of Mann-Whitney U-testing

\begin{tabular}{lccccccc}
\hline Variable & Obs. & $\begin{array}{c}\text { Rank } \\
\text { sum }\end{array}$ & Expected & $\begin{array}{c}\text { Adj. } \\
\text { variance }\end{array}$ & z & Prob z & Results \\
\hline $\begin{array}{l}\text { TE } \\
\text { Indonesia }\end{array}$ & 77 & 8814 & 7045.5 & & & & \\
TE & 105 & 7839 & 9607.5 & 122893.87 & 5.045 & 0.0000 & $\mathrm{TE}_{\text {Ind }}>$ \\
$\begin{array}{l}\text { Malaysia } \\
\text { Combined }\end{array}$ & 182 & 16653 & 16653 & & & & $\mathrm{TE}_{\text {Mal }}$ \\
\hline
\end{tabular}


Table 7.

Results of Mann-Whitney U-testing (Continued)

\begin{tabular}{|c|c|c|c|c|c|c|c|}
\hline Variable & Obs. & $\begin{array}{l}\text { Rank } \\
\text { sum }\end{array}$ & Expected & $\begin{array}{c}\text { Adj. } \\
\text { variance }\end{array}$ & $\mathbf{z}$ & Prob z & Results \\
\hline $\begin{array}{l}\text { PTE } \\
\text { Indonesia }\end{array}$ & 77 & 8814 & 7045.5 & \multirow{3}{*}{118654.77} & \multirow{3}{*}{5.108} & \multirow{3}{*}{0.0000} & \multirow{3}{*}{$\begin{array}{c}\mathrm{PTE}_{\text {Ind }}> \\
\mathrm{PTE}_{\text {Mal }}\end{array}$} \\
\hline $\begin{array}{l}\text { PTE } \\
\text { Malaysia }\end{array}$ & 105 & 7839 & 9607.5 & & & & \\
\hline Combined & 182 & 16653 & 16653 & & & & \\
\hline Variable & Obs. & $\begin{array}{c}\text { Rank } \\
\text { sum }\end{array}$ & Expected & $\begin{array}{c}\text { Adj. } \\
\text { variance }\end{array}$ & $\mathbf{z}$ & Prob z & Results \\
\hline $\begin{array}{l}\text { SE } \\
\text { Indonesia }\end{array}$ & 77 & 7355 & 7045.5 & \multirow{3}{*}{122681.32} & \multirow{3}{*}{0.884} & \multirow{3}{*}{0.3769} & \multirow{3}{*}{$\begin{array}{l}\mathrm{SE}_{\text {Ind }}= \\
\mathrm{SE}_{\text {Mal }}\end{array}$} \\
\hline $\begin{array}{l}\text { SE } \\
\text { Malaysia }\end{array}$ & 105 & 9298 & 9607.5 & & & & \\
\hline Combined & 182 & 16653 & 16653 & & & & \\
\hline
\end{tabular}

\subsection{Analysis}

The overall results for intertemporal efficiency, especially for technical efficiency (TE) and pure technical efficiency (PTE), show that Islamic banks in Indonesia are more efficient than Islamic banks in Malaysia. These results are similar to the overall results for regular TE and PTE presented in Table 1. The only difference is in scale efficiency (SE), where the regular SE of Indonesian Islamic banks was higher (more efficient) than that of Malaysian Islamic banks, while intertemporal $\mathrm{SE}$ of Indonesian Islamic banks was slightly lower (less efficient) than that of Malaysian Islamic banks.

The intertemporal efficiency results of this study confirm the regular efficiency results of Ascarya and Yumanita (2008) in which the TE and PTE of Indonesian Islamic banks were more efficient than those of Malaysian Islamic banks, even though the periods of study were different: this study used 2012-2018 data while Ascarya and Yumanita (2008) used 2002-2005 data.

On the other hand, the intertemporal efficiency results of this study were different from the regular efficiency results of Solikin et al. (2016), which looked at the 2008-2013 period and found that the efficiency of Indonesian Islamic banks was slightly below the average efficiency of ASEAN Islamic banks, while the efficiency of Malaysian Islamic banks was slightly above the average of ASEAN Islamic banks. These results implied that the efficiency of Indonesian Islamic banks was lower (less efficient) than that of Malaysian Islamic banks.

Moreover, although these three studies used similar intermediation approaches, they apparently applied slightly different input-output variables, as shown in Table 8. The input-output variables of this study are mostly similar to those of Ascarya and Yumanita (2008), which arrived at similar results. 
Table 8.

Input-output Variables of Different Studies

\begin{tabular}{lcc}
\hline Study & Inputs & Outputs \\
\hline $\begin{array}{l}\text { Ascarya \& Yumanita (2008): } \\
\text { regular DEA }\end{array}$ & $\begin{array}{c}\text { Total deposits, labour costs, and } \\
\text { fixed assets }\end{array}$ & Total financing, other income \\
\hline $\begin{array}{l}\text { Solikin et al. (2016): } \\
\text { regular DEA }\end{array}$ & $\begin{array}{c}\text { Total deposits, other liabilities, } \\
\text { and operational expense }\end{array}$ & $\begin{array}{c}\text { Total financing, placements in } \\
\text { other banks, securities }\end{array}$ \\
\hline $\begin{array}{l}\text { This study: regular DEA and } \\
\text { intertemporal DEA }\end{array}$ & $\begin{array}{c}\text { Total deposits, labour costs, and } \\
\text { fixed assets }\end{array}$ & $\begin{array}{c}\text { Total financing, operating } \\
\text { income, and investment } \\
\text { portfolio }\end{array}$ \\
\hline
\end{tabular}

Even though the regular DEA results of Ascarya and Yumanita (2008) and the regular DEA results of this study confirm our intertemporal DEA results, different results could still be possible for different periods of data and different inputoutput variables, as well as through use of a different DEA approach (regular vs. intertemporal).

The comparison of Ascarya and Yumanita's (2008) findings and this study in terms of efficiency results can be seen in Table 9. Indonesian Islamic banks showed improvement in TE, due to improvement in PTE, both for regular DEA and intertemporal DEA. Meanwhile, Malaysian Islamic banks showed deterioration of TE and PTE for regular DEA, but showed improvement in TE due to improvement in PTE for intertemporal DEA. Unfortunately, the SE of Islamic banks in Indonesia and Malaysia showed some deterioration in the aftermath of the global financial crisis.

Table 9.

Efficiency Results Comparison

\begin{tabular}{|c|c|c|c|c|}
\hline \multirow{3}{*}{$\begin{array}{l}\text { Country- } \\
\text { Efficiency }\end{array}$} & \multirow{3}{*}{$\begin{array}{c}\begin{array}{c}\text { Ascarya and } \\
\text { Yumanita (2008) }\end{array} \\
\text { Regular DEA } \\
\text { Score }\end{array}$} & \multicolumn{3}{|c|}{ Current study } \\
\hline & & \multirow{2}{*}{$\begin{array}{c}\text { Regular DEA } \\
\text { Score }\end{array}$} & \multicolumn{2}{|c|}{ Intertemporal DEA } \\
\hline & & & Score & Stability LDY \\
\hline \multicolumn{5}{|l|}{ Indonesia } \\
\hline TE & 0.724 & 0.754 & 0.774 & 0.034 \\
\hline PTE & 0.830 & 0.891 & 0.917 & 0.020 \\
\hline SE & 0.867 & 0.904 & 0.845 & \\
\hline \multicolumn{5}{|l|}{ Malaysia } \\
\hline TE & 0.684 & 0.541 & 0.751 & 0.169 \\
\hline PTE & 0.750 & 0.695 & 0.880 & 0.161 \\
\hline SE & 0.919 & 0.788 & 0.853 & \\
\hline
\end{tabular}

In addition, the efficiency stability represented by LDY scores revealed that the LDYs of Indonesian Islamic banks were much better in TE and PTE than those of Malaysian Islamic banks. Therefore, intertemporal DEA scores and LDY scores 
have confirmed that Indonesian Islamic banks were more efficient and more stable than Malaysian Islamic banks.

\section{CONCLUSIONS AND RECOMMENDATIONS}

\subsection{Conclusions}

Most studies measuring the efficiency of Islamic banks have used the regular DEA method, which only portrays certain times or periods of time, and so can only provide static results. This study uses intertemporal DEA or DEA window analysis to provide dynamic efficiency results for the Islamic banks under study.

The results indicate that the intertemporal efficiencies of Indonesian Islamic banks are higher (or more efficient) than those of Malaysian Islamic banks. Technical efficiency (TE) of Indonesian Islamic banks reached $77.4 \%$, which was higher than that of Malaysian Islamic banks at $75.1 \%$. Pure technical efficiency (PTE) of Indonesian Islamic banks reached 91.7\%, which was also higher than that of Malaysian Islamic banks at $88.0 \%$. The intertemporal TE and PTE of Indonesian Islamic banks have been proven to be significantly different from (higher than) those of Malaysian Islamic banks, even though Islamic banks in Indonesia emerged ten years after the first establishment of Islamic banks in Malaysia.

On the other hand, the intertemporal scale efficiency (SE) of Islamic banks in Indonesia reached $84.5 \%$, which is slightly lower than that of Islamic banks in Malaysia at $85.3 \%$ but not significantly different. Both Indonesian and Malaysian Islamic banks suffer from deterioration of $\mathrm{SE}$, which will eventually affect TE as a whole.

Nevertheless, the three most efficient Islamic banks were two Malaysian banks, namely Public Islamic Bank Berhad (1.000) and Maybank Islamic Berhad (0.987), followed by one Indonesian bank, namely Bank Syariah Mandiri (0.984).

Moreover, the stability of efficiency shows that the efficiencies of Islamic banks in Indonesia were more stable than those of Islamic banks in Malaysia, both in TE and PTE, especially as shown by LDY (largest difference between scores in the same year).

\subsection{Recommendations}

The efficiency of Islamic banks in Indonesia and Malaysia has shown improvement in PTE but deterioration in SE, indicating that improvement in TE has not been optimal. Recovery and improvement of SE are urgently needed. Islamic banks need to increase their capital to boost their economies of scale and consequently their efficiency, especially in terms of SE. Islamic banks which have not yet gone public could be encouraged to do so to increase their capital. Another possibility to increase size is the encouragement of mergers between small Islamic banks. Meanwhile, the regulator could provide supporting environments and incentives to encourage Islamic banks to improve their capital, including through going public or merging.

DEA is a measure of relative efficiency and, as this study covers only Islamic banks in Indonesia and Malaysia, further studies covering Islamic banks and conventional banks are needed to reveal the competitiveness of Islamic banks 
under dual banking systems. Further studies using other methods are also needed to confirm the results. In addition, studies to determine the root causes of SE deterioration are urgently needed to resolve the problems associated with it.

\section{REFERENCES}

Abbas, M., Azid, T., \& Hj Besar, M. H. A. (2016). Efficiency, Effectiveness and Performance Profile of Islamic and Conventional Banks in Pakistan. Humanomics, 32(1), 2-18.

Alqahtani, F., Mayes, D. G., \& Brown, K. (2017). Islamic Bank Efficiency Compared to Conventional Banks During the Global Crisis in the GCC region. Journal of International Financial Markets, Institutions and Money, 51, 58-74.

Ariss, R. T. (2010). Competitive Conditions in Islamic and Conventional Banking: A Global Perspective. Review of Financial Economics, 19(3), 101-108.

Ascarya \& Yumanita, D. (2006). Analisis Efisiensi Perbankan Syariah Di Indonesia Dengan Data Envelopment Analysis [Analysis of the Efficiency of Islamic Banking in Indonesia with Data Envelopment Analysis]. TAZKIA Islamic Finance and Business Review, 1(2), 101-124.

Ascarya, \& Yumanita, D. (2008a). Measuring the Competitiveness of Islamic Banking in Indonesian Dual Banking System. TAZKIA Islamic Finance and Business Review, 3(2), 72-89.

Ascarya, \& Yumanita, D. (2008b). Comparing the efficiency of Islamic banks in Malaysia and Indonesia. Bulletin of Monetary Economics and Banking, 11(2), 95119.

Bank Negara Malaysia. (2019). Financial Stability. Retrieved from http://www.bnm. gov.my.

Banker, R. D., Charnes, A., \& Cooper, W. W. (1984). Some Models for Estimating Technical and Scale Inefficiencies in Data Envelopment Analysis. Management Science, 30(9), 1078-1092.

Beck, T., Demirgüç-Kunt, A., \& Merrouche, O. (2010). Islamic vs. Conventional Banking: Business model, Efficiency and Stability. Policy Research Working Paper no. WPS 5446. Washington, DC: World Bank. Retrieved from http://documents. worldbank.org/curated/en/482731468333056240/Islamic-vs-conventionalbanking-business-model-efficiency-and-stability

Coelli, T. J., Rao, D. S. P., O’Donnell, C. J., \& Battese, G. E. (2005). An Introduction to Efficiency and Productivity Analysis. New York: Springer Science \& Business Media.

Charnes, A., Clark, T., Cooper, W. W., \& Golany, B. (1985). A Developmental Study of Data Envelopment Analysis in Measuring the Efficiency of Maintenance Units in the US Air Forces. Annals of Operations Research, 95-112.

Charnes, A., Cooper, W. W., \& Rhodes, E. (1978). Measuring the Efficiency of Decision Making Units. European Journal of Operational Research, 2(6), 429-444.

Cooper, W W., Seiford, L. M., \& Tone, K. (2007). Data Envelopment Analysis: A Comprehensive Text with Models, Applications, References and DEA-Solver. New York, NY: Springer Science \& Business Media. 
Cooper, W W., Seiford, L M., \& Zhu, J. (2011). Handbook on Data Envelopment Analysis. New York, NY: Springer Science \& Business Media.

Freixas, X., \& Rochet, J.-C. (2008). Microeconomics of Banking. Cambridge, MA: MIT Press.

Jahanshahloo, G. R., Soleimani-Damaneh, M., \& Ghobadi, S. (2015). Inverse DEA Under Inter-Temporal Dependence Using Multiple-Objective Programming. European Journal of Operational Research, 240(2), 447-456.

Kamarudin, F., Hue, C. Z., Sufian, F., \& Mohamad Anwar, N. A. (2017). Does Productivity of Islamic Banks Endure Progress or Regress? Empirical Evidence Using Data Envelopment Analysis Based Malmquist Productivity Index. Humanomics, 33(1), 84-118.

Mohieldin, M. (2012). Realizing the Potential of Islamic Finance. The World Bank: Economic Premise, 77(67644), 1-7.

Otoritas Jasa Keuangan. (2018). Laporan Perkembangan Keuangan Syariah Indonesia 2018 [2018 Indonesia Sharia Financial Development Report.]

OJK. (2019). Sharia Banking Statistics. https://ojk.go.id.

Řepková, I. (2014). Efficiency of the Czech Banking Sector Employing the DEA Window Analysis Approach. Procedia Economics and Finance, 12, 587-596.

Řepková, I. (2014). Efficiency of the Slovak Commercial Banks Applying the DEA Window Analysis. Economics and Management Engineering, 8(5), 1320-1325.

Sharma, D., Sharma, A. K., \& Barua, M. K. (2013). Efficiency and Productivity of Banking Sector: A Critical Analysis of Literature and Design of Conceptual Model. Qualitative Research in Financial Markets, 5(2), 195-224.

Shawtari, F. A., Ariff, M., \& Razak, S. H. A. (2015). Efficiency assessment of banking sector in Yemen using data envelopment window analysis. Benchmarking: An International Journal, 22(6), 1115-1140.

Solihin, S., Achsani, N. A., \& Saptono, I. T. (2016). Islamic Banking and the Economic Integration in ASEAN. Buletin Ekonomi Moneter dan Perbankan, 19(1), 81-106.

Sufian F., \& Majid, M. Z. A. (2006). Banks' Efficiency and Share Prices in an Emerging Market: A DEA Window Analysis Approach. Oxford Journal: An International Journal of Business E Economics, 1(1), 6-20.

The World Bank. (2019). Population, Total. Retrieved from https://data.worldbank.org/ indicator/SP.POP.TOTL?view=chart

Wanke, P., Hassan, M. K., \& Gavião, L. O. (2017). Islamic Banking And Performance In The ASEAN Banking Industry: A Topsis Approach With Probabilistic Weights. International Journal of Business \& Society, 18(1), 129-150.

Wanke, P., Azad, M. A. K., \& Barros, C. P. (2016). Financial Distress and the Malaysian Dual Baking System: A Dynamic Slacks Approach. Journal of Banking \& Finance, 66, 1-18.

Webb, R. (2003). Levels of Efficiency in UK Retail Banks: A DEA Window Analysis. International Journal of the Economics of Business, 10(3), 305-322. 


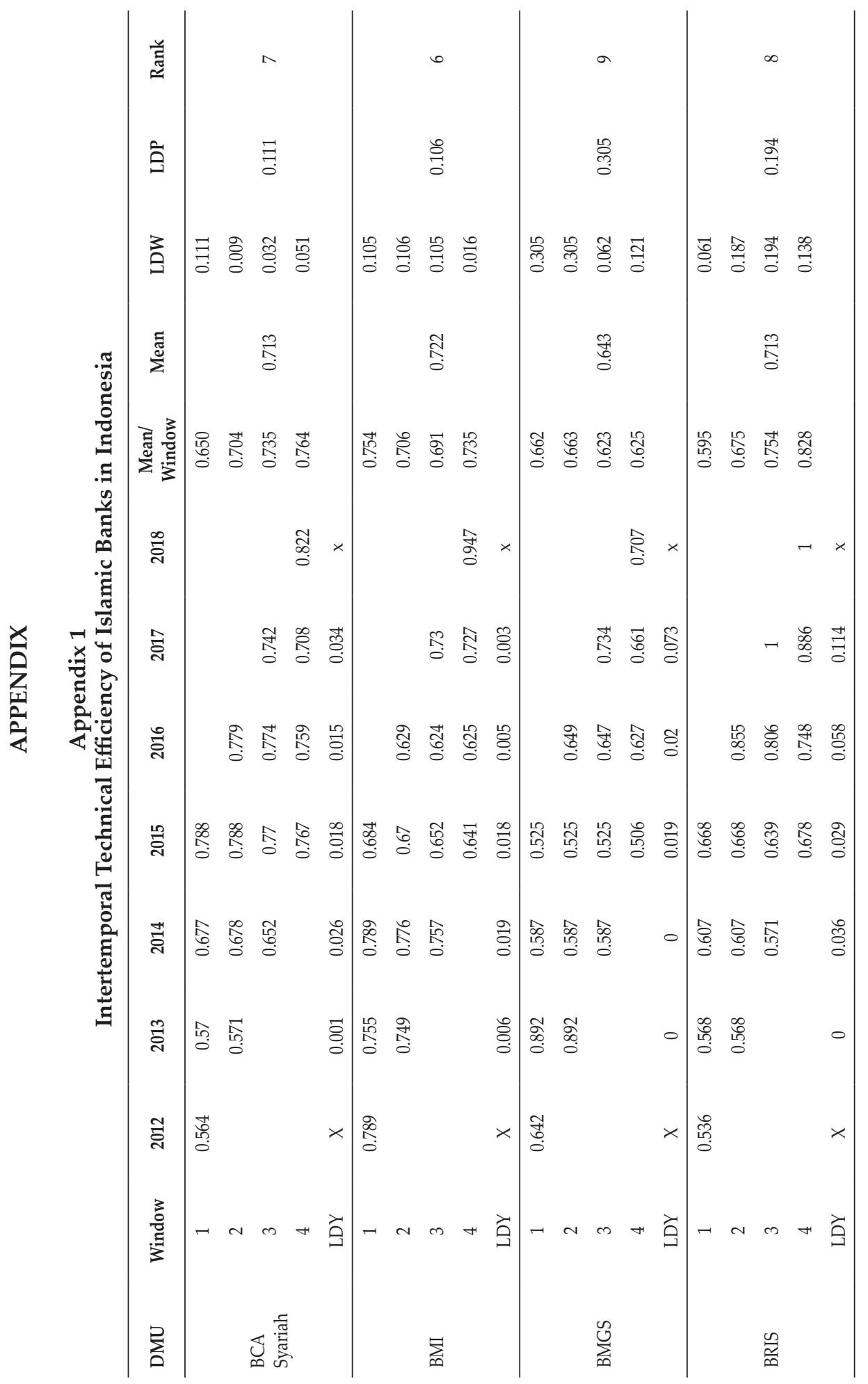




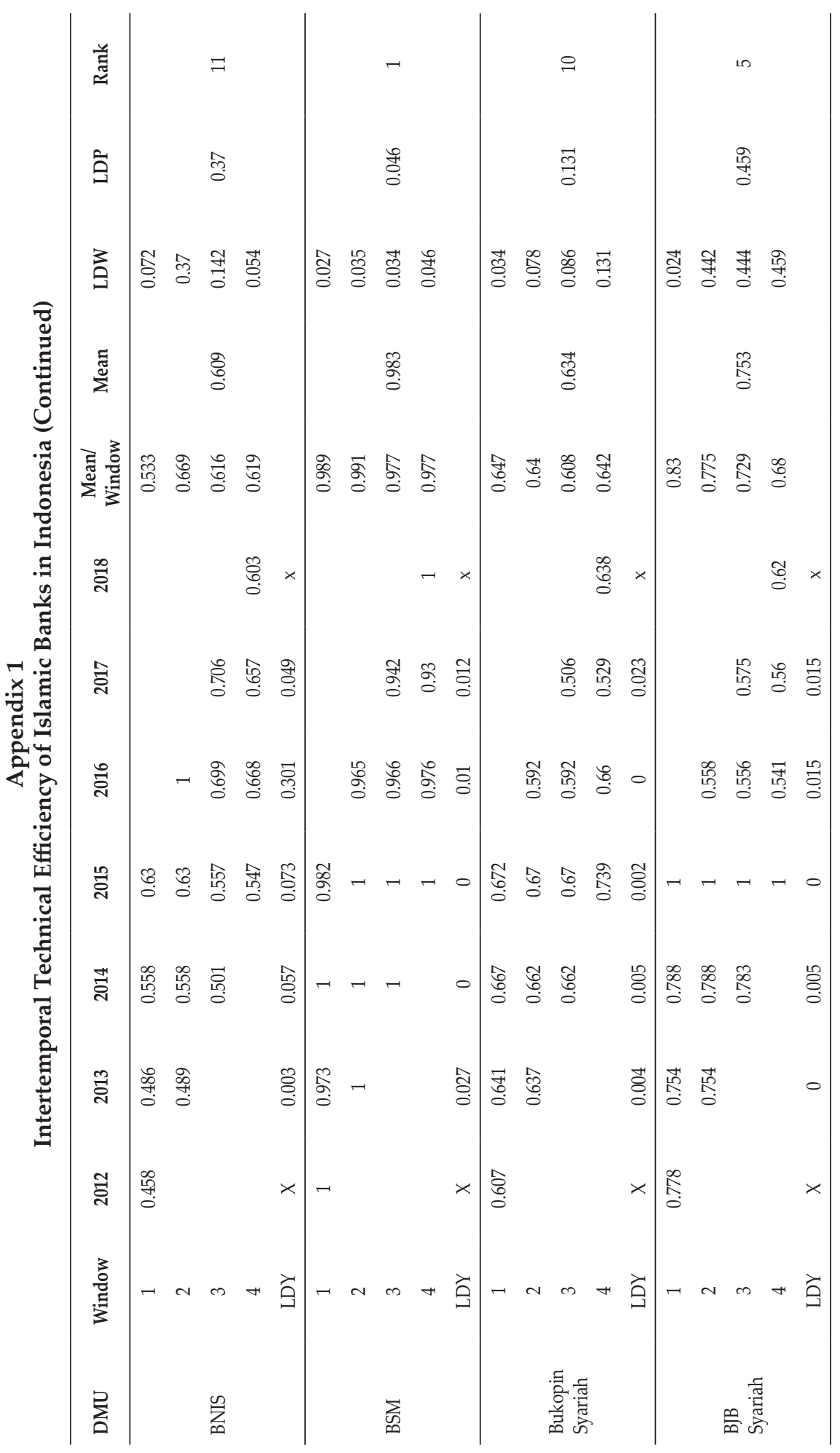




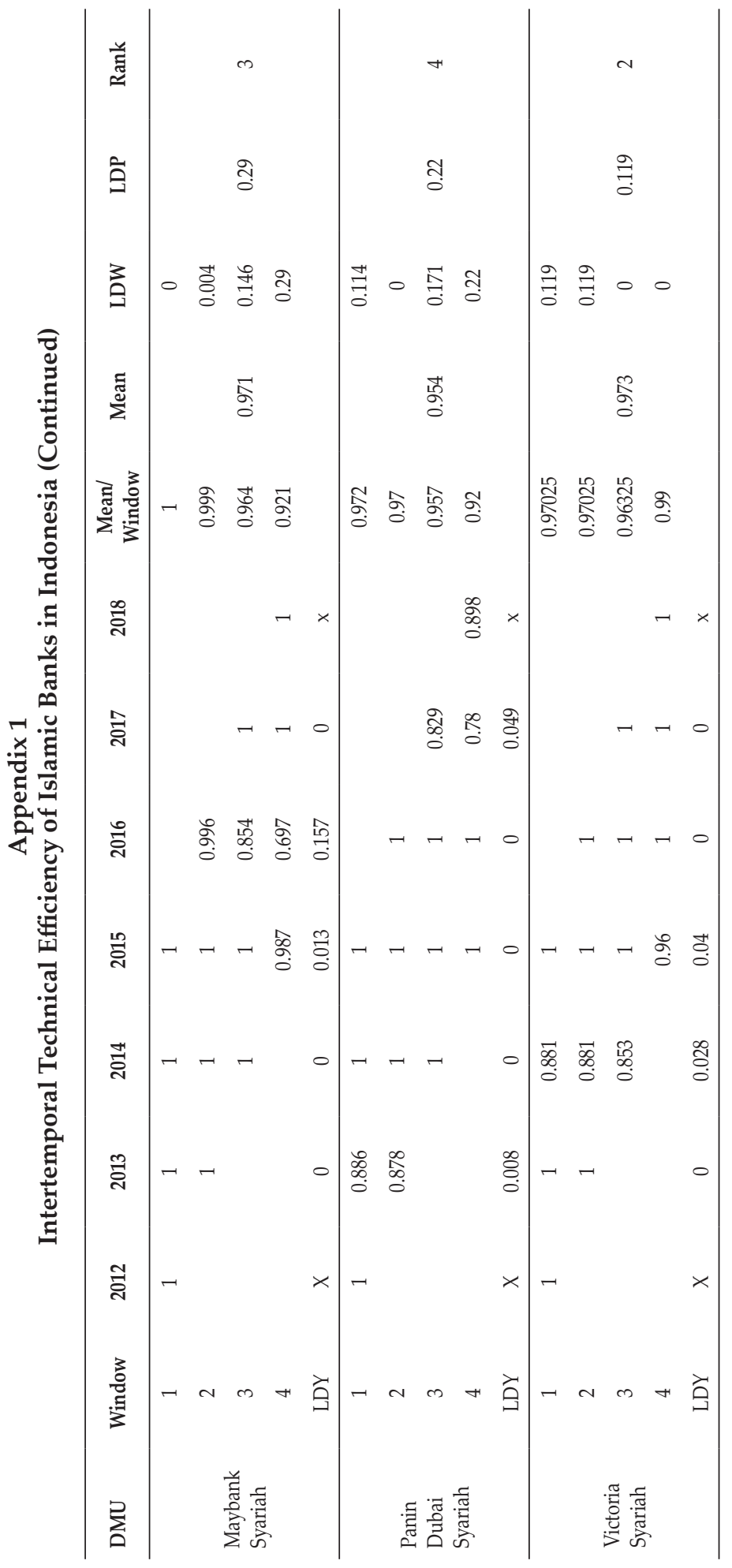




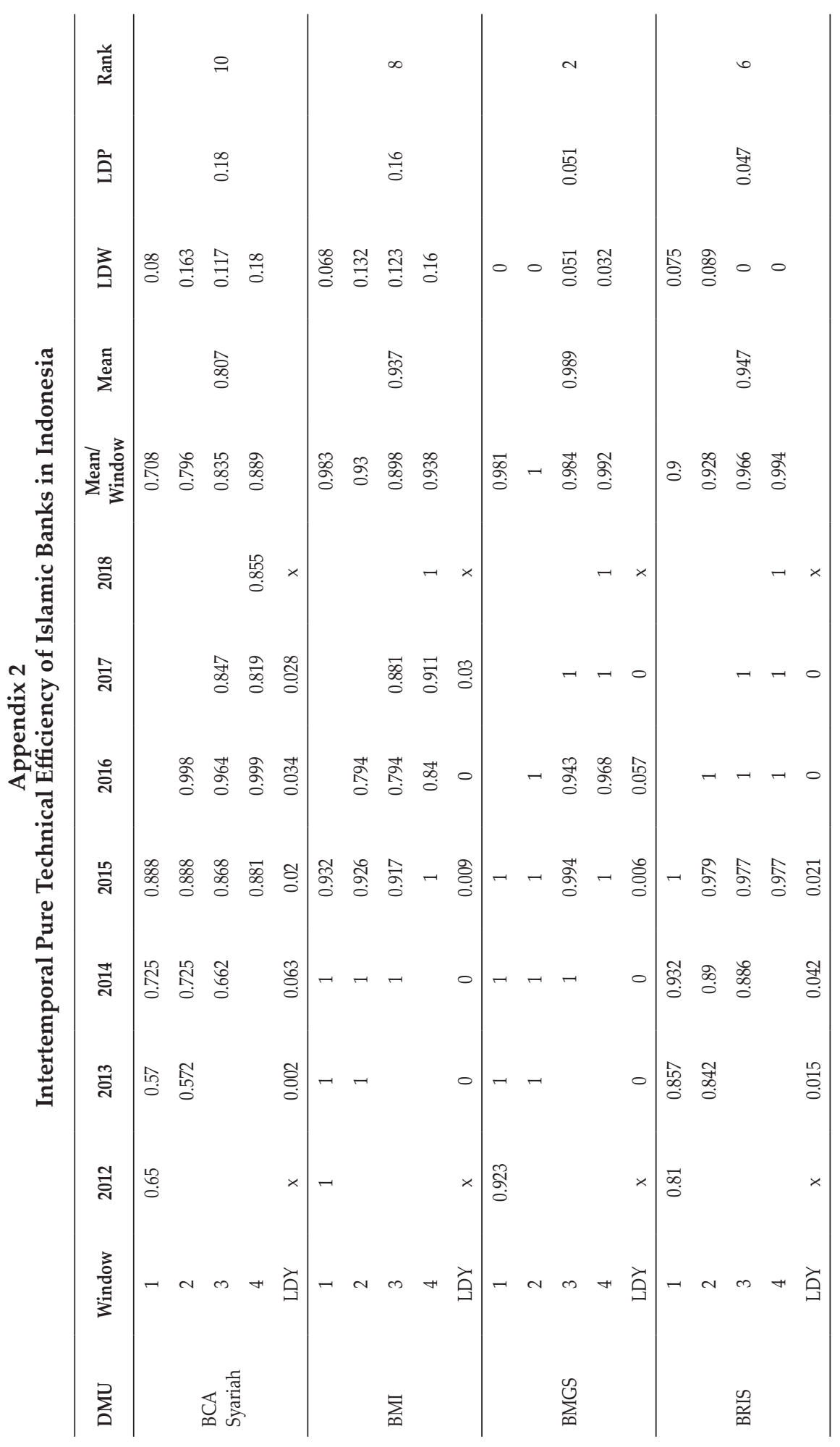




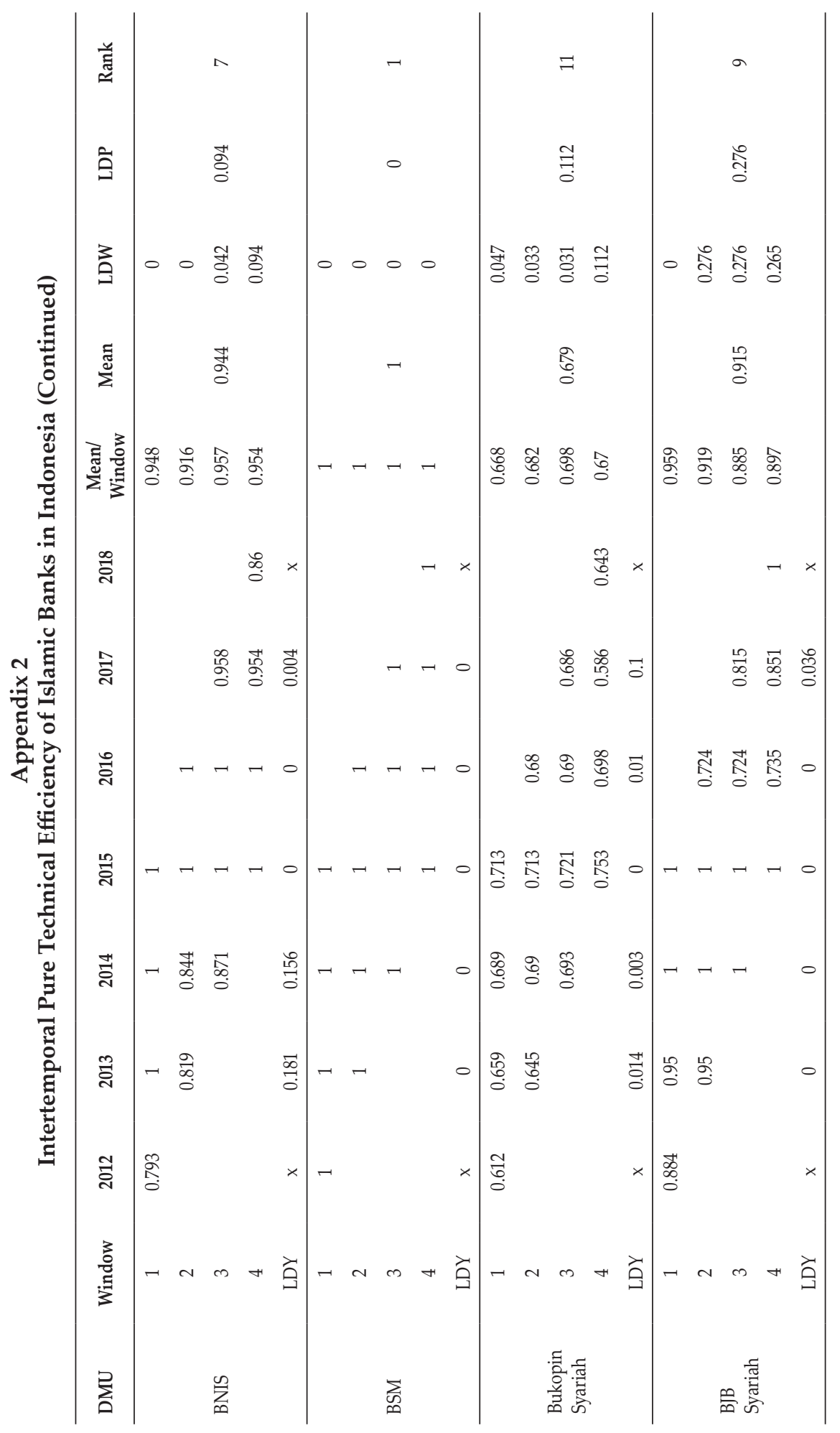




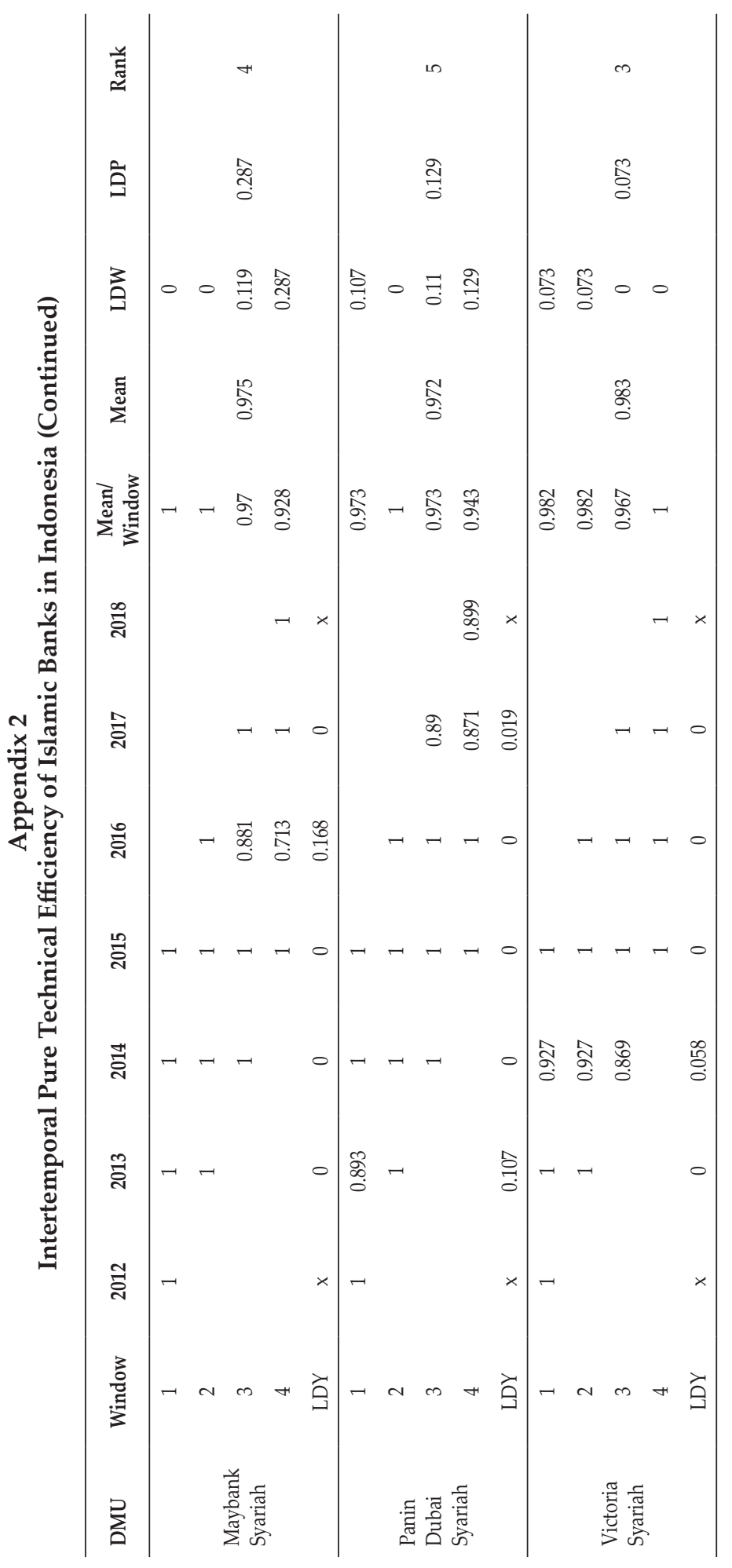




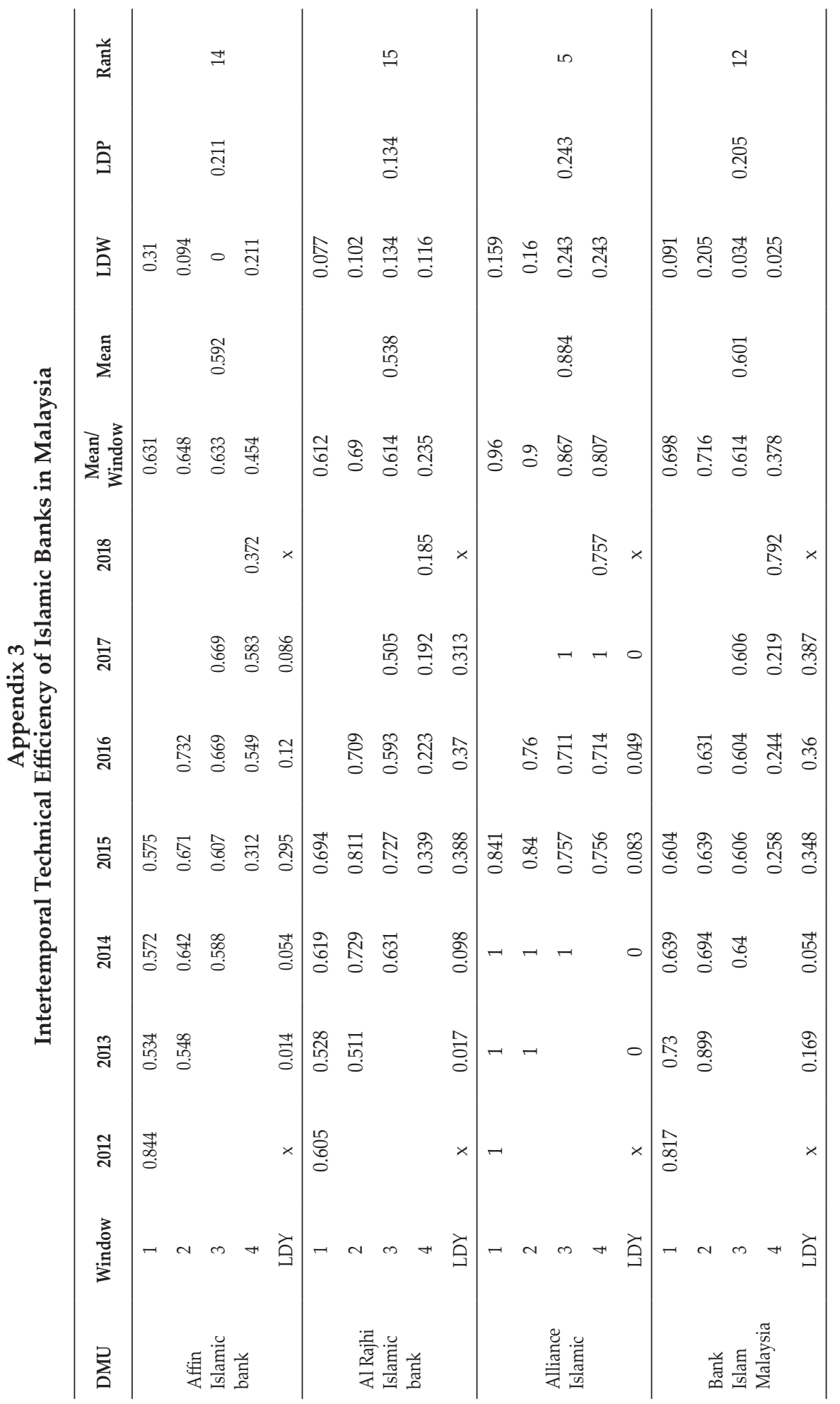




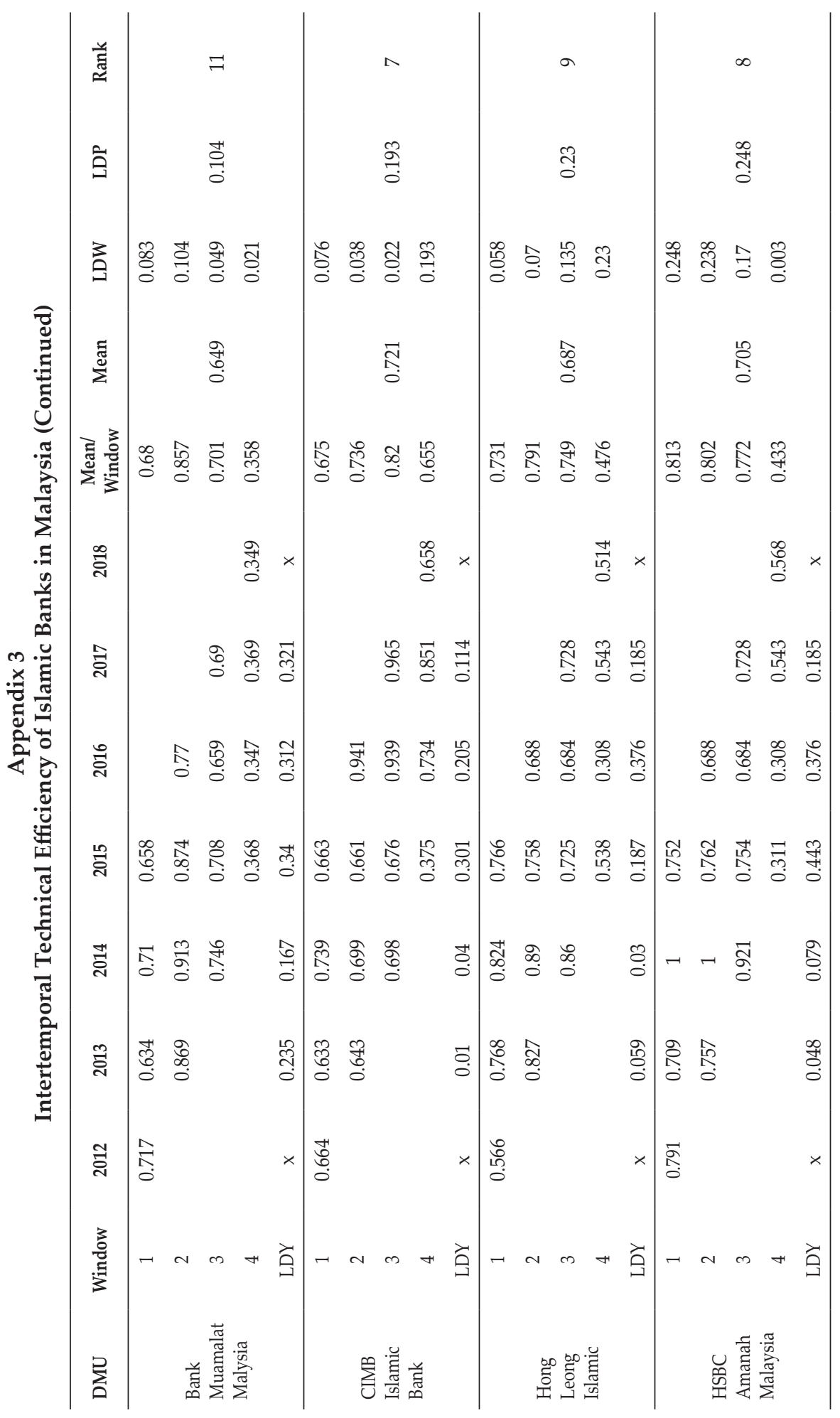




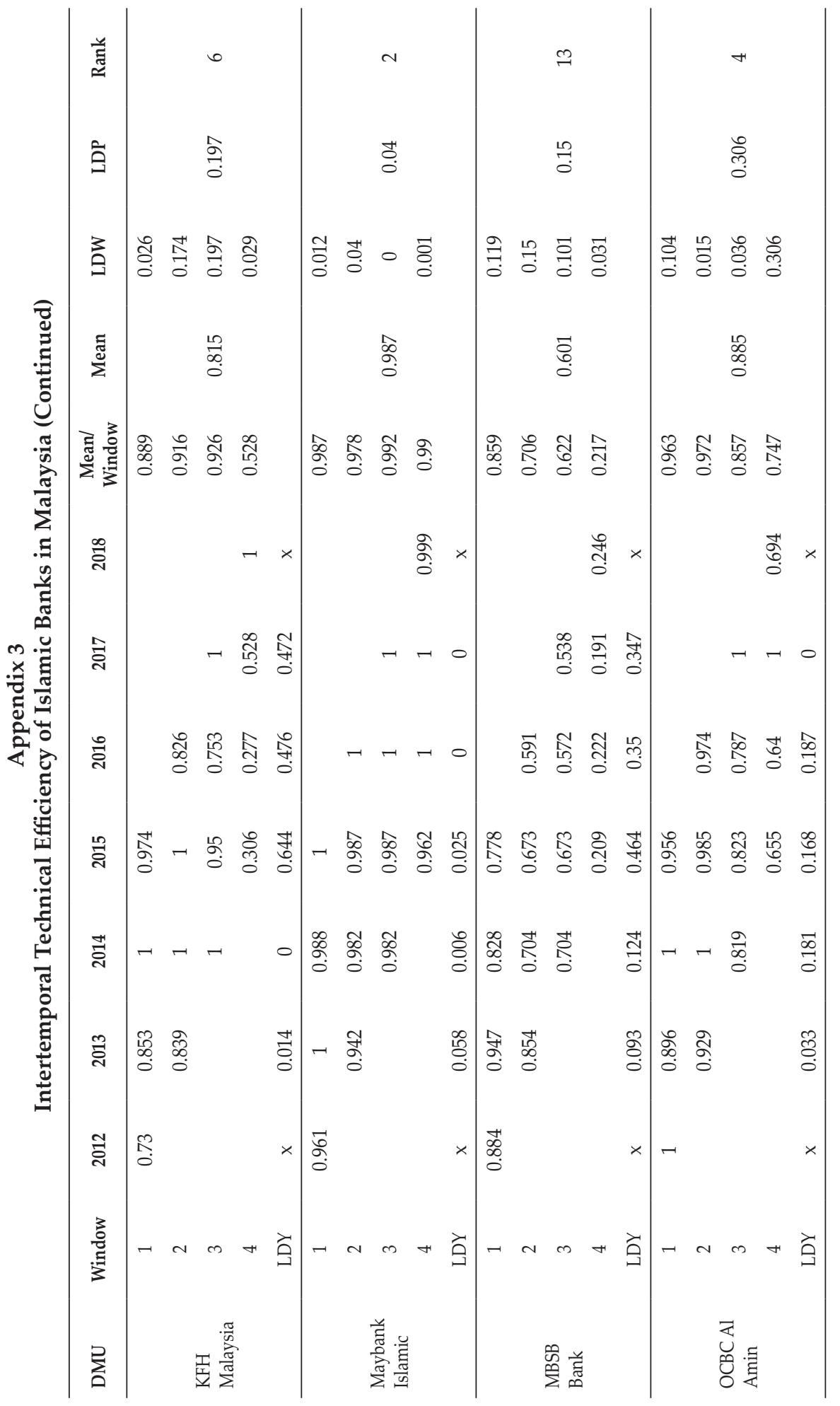




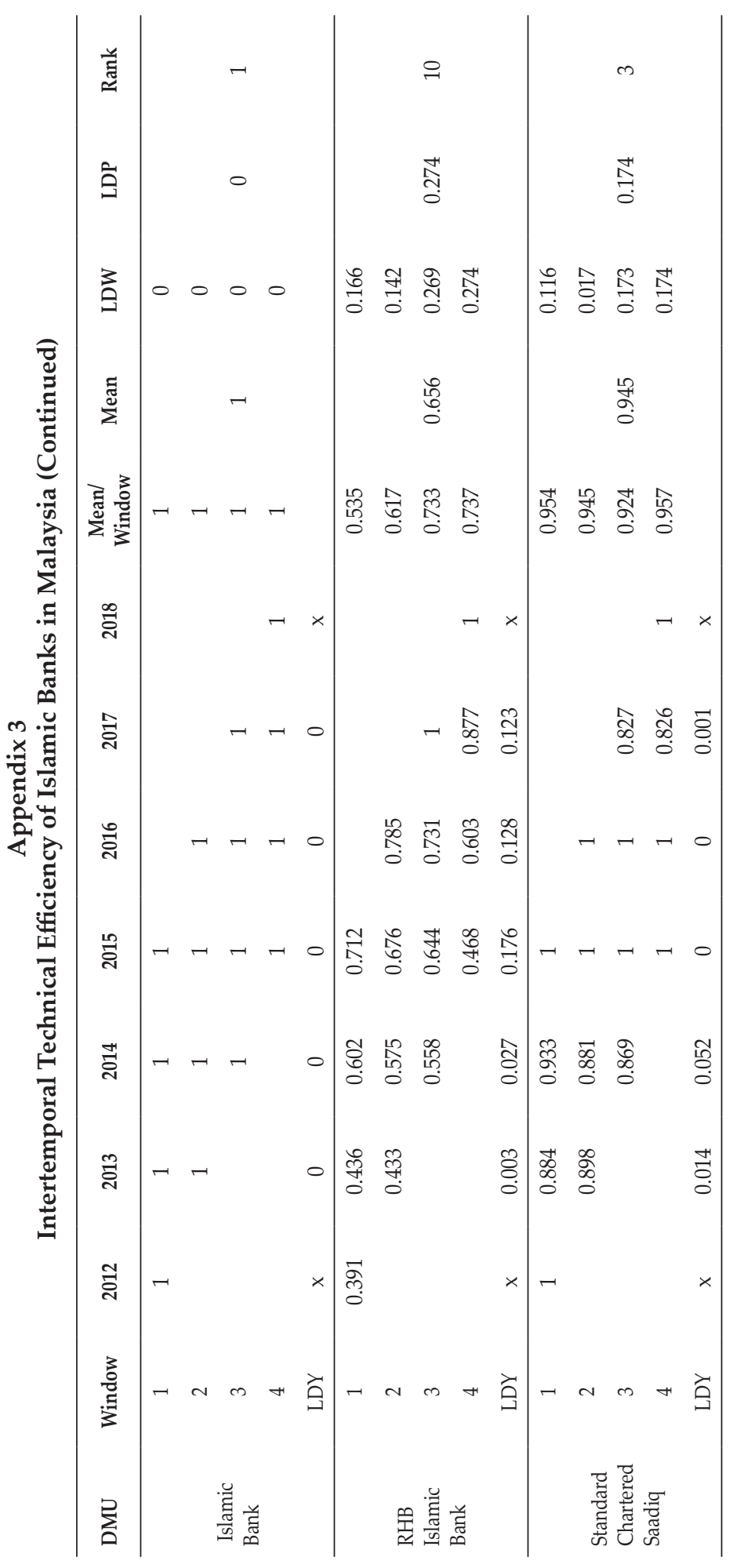




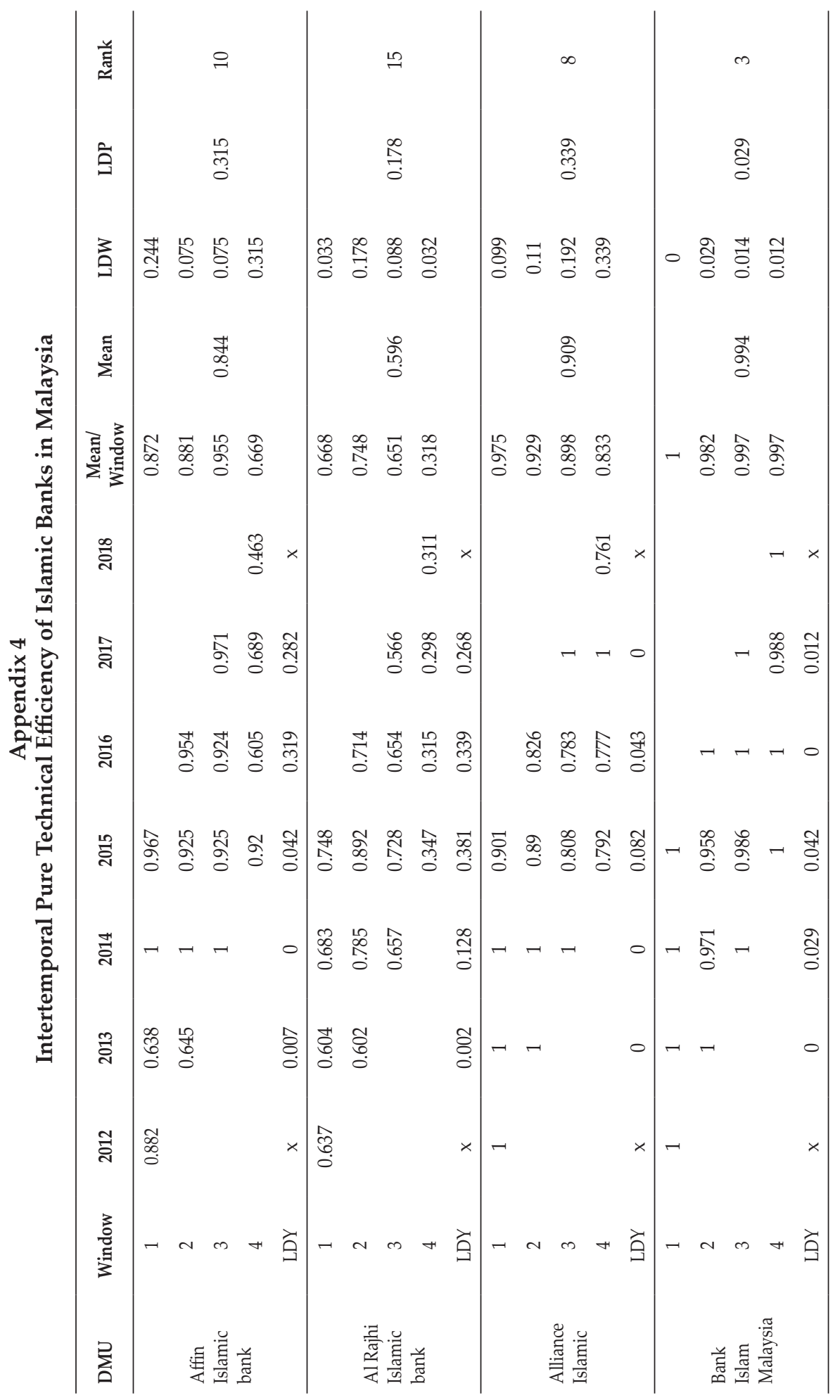




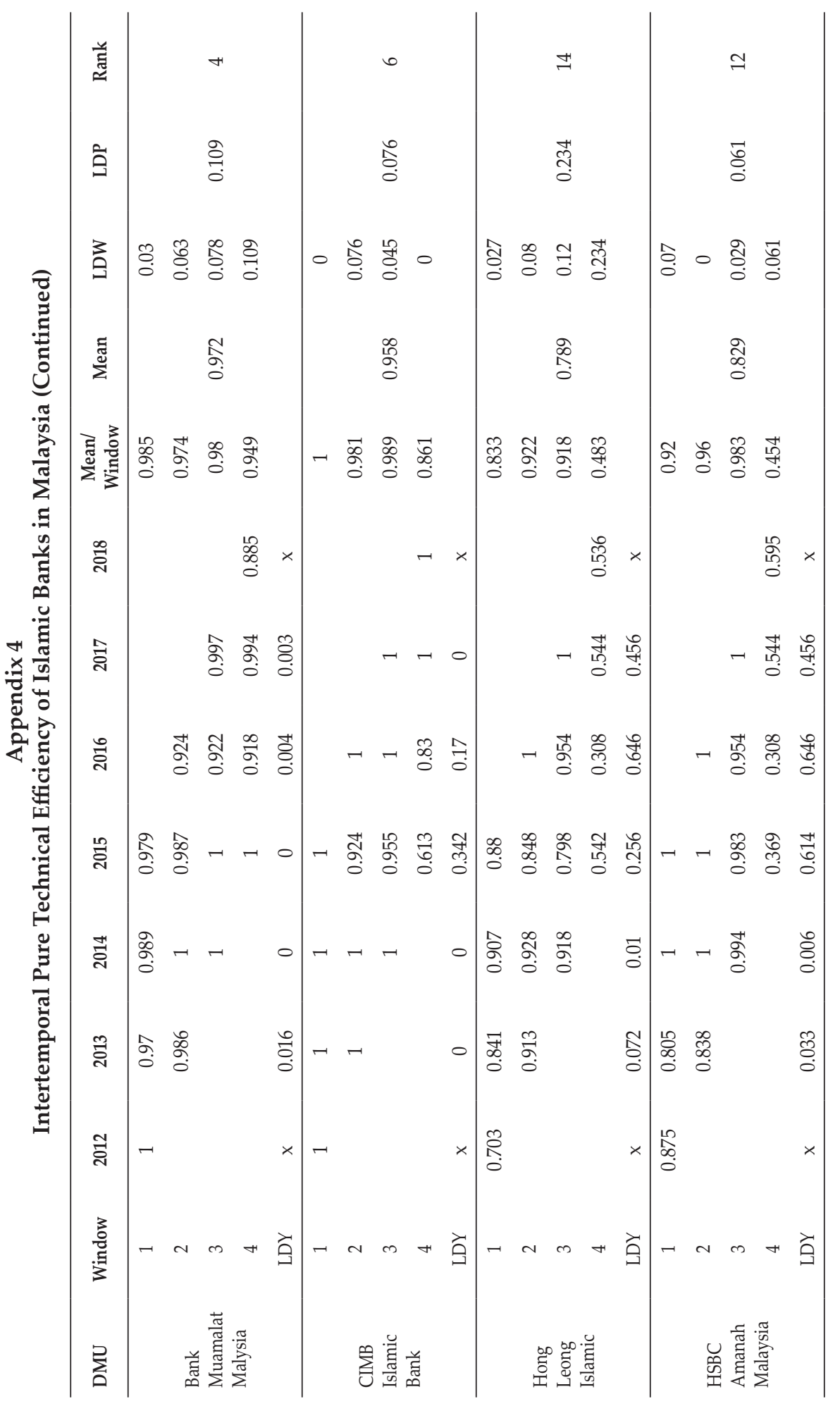




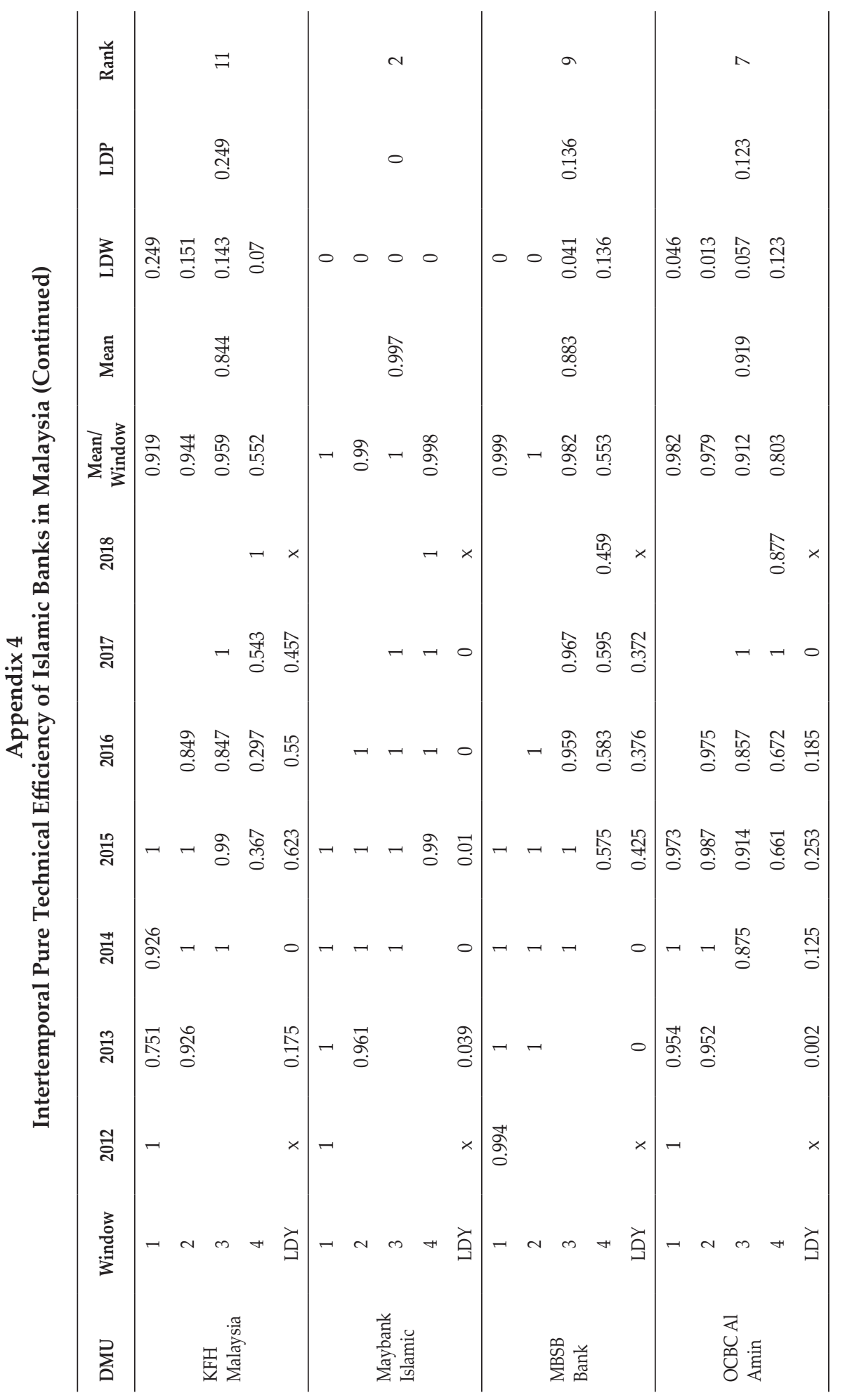




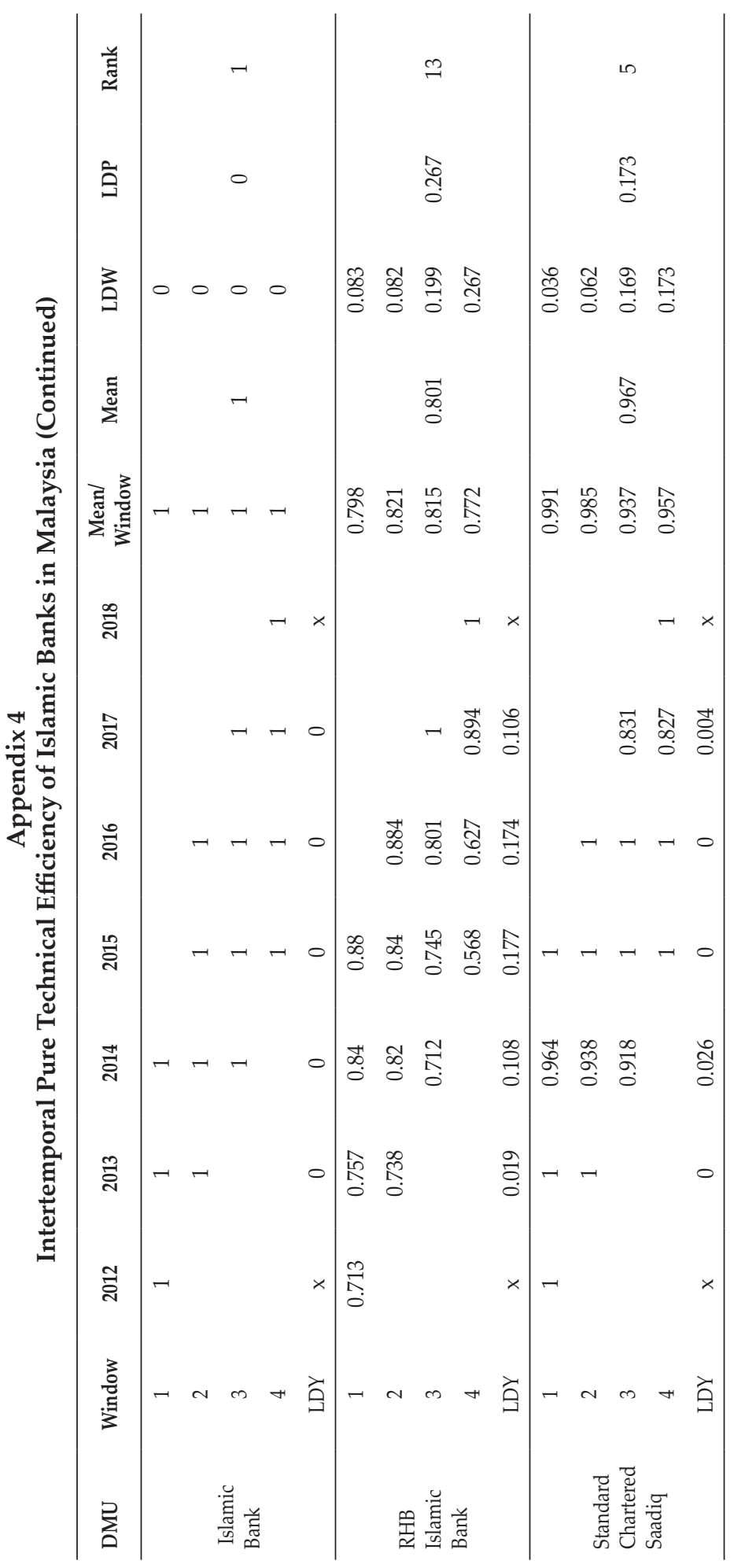


This page is intentionally left blank 